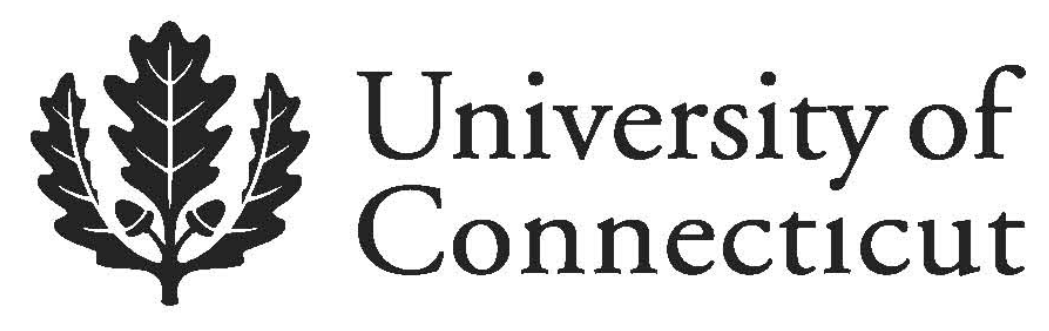

Department of Economics Working Paper Series

\title{
Consumption and Social Identity: Evidence from India
}

Melanie Khamis

Wesleyan University \& IZA

Nishith Prakash

University of Connecticut, CReAM, \& IZA

Zahra Siddique

IZA

Working Paper 2012-28

April 2012

365 Fairfield Way, Unit 1063

Storrs, CT 06269-1063

Phone: (860) 486-3022

Fax: (860) 486-4463

http://www.econ.uconn.edu/

This working paper is indexed on RePEc, http://repec.org 


\title{
Consumption and Social Identity: Evidence from India*
}

\author{
Melanie Khamis \\ Wesleyan University and $\mathrm{IZA}^{\dagger}$
}

\author{
Nishith Prakash \\ University of Connecticut, CReAM and IZA
}

\author{
Zahra Siddique \\ $\mathrm{IZA}^{\S}$
}

April 23, 2012

\begin{abstract}
We examine spending on consumption items which have signaling value in social interactions across groups with distinctive social identities in India, where social identities are defined by caste and religious affiliations. Using nationally representative micro data on household consumption expenditures, we find that disadvantaged caste groups such as Other Backward Castes spend eight percent more on visible consumption than Brahmin and High Caste groups while social groups such as Muslims spend fourteen percent less, after controlling for differences in permanent income, household assets and household demographic composition. The differences across social groups are significant and robust and these differences persist within different sub populations. We find that the higher spending of OBC households on visible consumption is diverted from education spending, while Muslim households divert spending from visible consumption and education towards greater food spending. Additionally, we find that these consumption patterns can be partly explained as a result of the status signaling nature of the consumption items. We also discuss alternative sources of differences in consumption patterns across groups which stem from religious observance.
\end{abstract}

JEL Classification: D12, D70, O10

Keywords: Households, Consumption, India

${ }^{*}$ We are grateful to Arnab Basu, Christopher Barrett, Nancy Chau, Aimee Chin, Deborah Cobb-Clark, Mukesh Eswaran, Thomas Gall, Ira Gang, Daniel Hamermesh, David Jaeger, Neha Khanna, Kundan Kishor, Stephan Klasen, Stephen Ross, Mikhael Shor, Uwe Sunde, Christopher Taber and seminar participants at IZA, University of Goettingen, the IZA workshop on Cognitive and non-Cognitive Skills, Dalhousie University, the Department of Applied Economics at the University of Minnesota, the 2011 ASREC annual meeting, Cornell University, Bristol University, the 6th IZA/World Bank conference, the Lahore University of Management Sciences, Stockholm University, Uppsala University, CUNY Graduate Center, World Bank (Poverty and Applied Micro seminar), the NEUDC 2011 conference and the Royal Economic Society 2012 conference for comments. We are also indebted to Ram Singh for implementation of the online survey as well as to students who participated in the survey at the Delhi School of Economics. All errors are our own.

${ }^{\dagger}$ Department of Economics, Wesleyan University, PAC 222, 238 Church Street, Middletown, CT 06459, USA (E-mail: mkhamis@wesleyan.edu).

${ }^{\ddagger}$ Department of Economics and Human Rights Institute, 341 Mansfield Road, Unit 1063, Monteith Room No. 340, University of Connecticut, Storrs, CT 06269-1063, USA (E-mail: nishith.prakash@uconn.edu).

${ }^{\S}$ Corresponding Author: Institute for the Study of Labor (IZA), Schaumburg-Lippe-Str. 5-9, Bonn D53113, Germany (E-mail: siddique@iza.org, Phone: +49 2283894 522, Fax: +49 2283894 510). 


\section{Introduction}

'Pramod: We were an underdeveloped country. Now we are a developing country. Since the last ten years, status is coming up: car, TV.

Ila: A car, bungalow, a lot of money. If you have a lot of money, then your status is high. Whether you have good children, a good wife, credit in the society, [all that] is secondary.

Pramod: Earlier, money was important, but it was spent on gold and land, not on luxury items.

Ila: Now, one should have a washing machine, a refrigerator, motorcycles, a nice house, decorations.'[22]

Progress made towards achieving the Millenium Development Goal of reducing the number of people living under one and two dollars a day has been largely due to the rise in incomes that has taken place in India and China. Income growth in India has been consistently high since India's trade liberalization and opening of the economy. With changing income distributions, there may be a race towards consumption to signal status that has important and adverse welfare consequences (by causing negative externalities and leading to inefficient equilibrium outcomes as described in Frank (2005) or by its role in poverty traps as described in Moav and Neeman (2008)).

There is a well established literature within theoretical economics of consumption as a means to signal status, first described by Veblen (1899) and formalized in work by Basu (1989), Ireland (1994) and Bagwell and Bernheim (1996). A smaller but growing empirical literature tests for status signaling consumption. Some recent papers studying positional concerns in a developed country context are Kuhn et al (2011) and Ravina (2007). Charles et al (2009) examine status signaling consumption across racial and ethnic groups in the US. They find that African Americans, with lower incomes on average than whites, spend more on visible consumption and that these patterns of consumption spending can be completely described by status signaling.

Consumption to signal status is also undertaken by the poor in developing countries. Banerjee and Duflo (2006) show that median households in Udaipur spend ten percent of their annual budget on festivals and five percent on tobacco and alcohol. This is despite that eighty six percent of the population in this area lives below the poverty line. Bloch et al (2004) provide evidence of status signaling consumption by rural Indian households in Karnataka by examining spending on wedding expenditures.

Our work draws inspiration from and uses a similar empirical strategy as that in Charles et al (2009) 
(which examines conspicuous consumption across race in the US) to examine differential spending in conspicuous consumption across groups with distinctive social identities in India. While all empirical work on conspicuous consumption in a developing country context uses detailed village level data from a few villages in individual districts, our work uses nationally representative data which documents nationwide trends. Our contribution is to verify the existence of conspicuous consumptions at the national level lending external validity to current research on conspicuous consumption in developing countries. Our approach is also useful for devising policies at the national level in India since the trends we identify are nation-wide trends. Indeed, our study is the first to examine nation-wide visible consumption in India across a wide range of consumption items. We find large and significant differentials in visible consumption across groups with distinctive social identities. We also test the implications of models that describe such visible consumption as a means to signal status, and find that these implications are satisfied. However, we cannot explain all the patterns of consumption spending we observe across groups with status signaling alone. We discuss a number of alternative mechanisms which stem from religious observance and which could also be driving the consumption patterns we observe.

By their nature, status signaling consumptions depend on what others believe about an individual's income. The beliefs of individual income in turn depend on the income distribution of the reference group to which an individual is perceived to belong to. In the Indian context the relevant reference groups are those with distinctive identities defined by caste and religion which are visible in a variety of social interactions. Caste and religious affiliations prescribe customs, rules and norms of behavior, including naming conventions so that such affiliations (which religion or caste a person belongs to) are visible in all non-anonymous social interactions. An example is the Yadavs in Bihar and Uttar Pradesh who belong to the OBC caste groups. Caste and religious affiliations also prescribe group specific rituals and traditions such as wearing of turbans by Sikh men, wearing beards by Muslim men, as well as rules for purity in the caste system which necessitate that low caste status be apparent so that such affiliations are visible in anonymous social interactions as well. The Adivasi social group is similar to Native Americans in the US or Aboriginals in Australia. They are easily identifiable due to features such as geographical isolation, simple technology and condition of living, a general backwardness to the practise of animalism, tribal language, physical features, etc.

Given the Indian context and following a similar strategy as Charles et al (2009), we define the relevant reference group for the study of status signaling consumption by space and social group, ie as others in 
the same district who belong to the same caste and religious group.

The focus of our study is spending on visible consumption items. These are items which are associated with high income and are easily observable in social interactions as a sign of luxury or a signal of wealth. The categorization of such items depends on the social context. All existing research on conspicuous consumption in developing countries assumes which consumption items are conspicuous (such as wedding expenditures or expenditures on social functions). Rather than take this approach, we categorize such items in the Indian context by carrying out a survey in India. The results of this survey give us a categorization which is consistent with common sense. We use nationally representative micro data on household consumption in the 2005 Indian Human Development Survey (IHDS) to study differences in conspicuous consumption across groups with distinctive social identities. We find that disadvantaged low caste groups also known as Other Backward Castes (OBC), spend significantly more on status signaling consumption than Brahmin and High Caste groups with a higher social standing in society. At the same time we find that Muslims, a social group very similar to the $\mathrm{OBC}$ in income and total expenditure distributions, spend significantly less on visible consumption items than Brahmin and High Caste households.

We find that $\mathrm{OBC}$ households spend approximately eight percent more on visible consumption than comparable High Caste and Brahmin households. Muslim households spend fourteen percent less on visible consumption than comparable High Caste and Brahmin households. While the magnitude of the difference varies within different sub populations, we find that the sign of the difference is fairly consistent. OBC households spend more on visible consumption whether we examine urban households only or rural households only. OBC households also spend more on visible consumption whether we examine households with highly educated household heads, households with less educated household heads, households with older household heads or households with a young household head. Similarly for Muslim households we find that these households spend less on visible consumption when we examine urban households only, rural households only, households with highly educated household heads, households with less educated household heads, households with older household heads or households with a young household head.

We also find that the higher spending of OBC households on visible consumption is diverted from education spending, while Muslim households divert spending from visible consumption and education towards greater food spending. Examining specific components of visible consumptions we find that the higher spending of OBC households comes from higher spending on clothing, repairs, house rent and entertainment, while the lower spending of Muslim households comes from their lower spending on social 
functions, clothing and recreation goods.

We find the same patterns of consumption spending when we exclude spending on furniture and repairs from our measure of visible spending or when we use an alternative weighted measure of visible consumption.

Some of the gaps in visible consumption that we observe across groups with distinctive social identities can be explained as a result of the status signaling nature of such consumption. OBC households spend more on visible consumption to distinguish themselves from others in their reference group (defined as other OBCs in the same district). However, we cannot explain the lower spending on visible consumption by Muslim households compared to other social groups by status signaling models alone. We discuss a number of alternative mechanisms which stem from religious observance and which could also be playing an important role.

Our work has policy importance in the debate on how to transform economic growth to include disadvantaged social groups. Increases in income are not necessarily spent on items such as education and health; disproportionately consumption spending may be diverted to signal status. Such diversion may be more important for some groups in society compared to others and may be symptomatic of dynamic inefficiencies in the economy.

The remainder of this paper is organized as follows. Section 2 provides background on social groups in India. Section 3 describes the data. Section 4 presents the empirical framework. Section 5 presents the result on consumption spending by groups with distinctive social identities in India. Section 6 concludes.

\section{Background}

A multi-ethnic and multi-cultural society, India has a variety of religions and cultures. The dominant religious group is the Hindu religion (according to the 2001 Census of India approximately 80.5\% of the population is Hindu), but there are also large numbers of Muslims (13.5\% of the population), Christians (2.3\% of the population), Sikhs (1.9\% of the population) and other religious groups. Some of these groups are regionally concentrated (for instance Christians in the North East and in the states of Goa and Kerala, Sikhs in the Northern states of Punjab, New Delhi and Haryana). All of these are groups with very distinctive social identities, cultures, customs and norms. Another important and historically disadvantaged group which is outside the Hindu religion and the caste system is the Tribals (now referred as Adivasis or Scheduled Tribes). 
Within the Hindus, there are important distinctions across caste. The caste system is a system of social stratification in which classes are defined by endogamous hereditary groups, often termed jatis or castes. The caste system is believed to be as old as 3000 years. The word caste derives from the Portuguese 'casta', meaning breed, race, or kind. Among the Indian terms that are sometimes translated as caste are varna, jati, jat, biradri, and samaj. All of these terms refer to ranked groups of various sizes and breadth. Varna, or color, actually refers to large divisions that include various castes; the other terms include castes and subdivisions of castes sometimes called sub-castes.

The caste system consists of the following broad divisions (or varnas): Brahmins (Priests), Kshatriyas (Warriors), Vaisyas (Merchant), Sudras (Servants), and Untouchables (outcasts, lowest menial jobs, now referred as Dalits or Scheduled Castes). In independent India, Other Backward Classes is added as a new category $(\mathrm{OBC})$. The $\mathrm{OBC}$ category consists of castes that are just above the Dalits and largely belong to the upper sections of Shudra category, with a few lower ranking Kshatriyas jatis being included. Each of the five caste groups are distinguished based on their own customs and rules which define an individual's status, behavior, rituals, occupation, food, and marriage among other characteristics. ${ }^{1}$

There exists some correlation between ritual rank on the caste hierarchy and economic prosperity. Members of higher-ranking castes tend, on the whole, to be more prosperous than members of lowerranking castes. Many low-caste people live in conditions of great poverty and social disadvantage. ${ }^{2}$ In independent India, affirmative action policies have been geared towards the Dalits, Adivasis and OBC.

\section{Data}

\subsection{India Human Development Survey}

We use consumption data from the 2005 India Human Development Survey (IHDS), a nationally representative household data set collected by the National Council of Applied Economic Research in New Delhi and the University of Maryland (Desai, Reeve and NCAER 2009). ${ }^{3}$

The advantage of using this survey is that it includes many questions that are not asked in the larger

\footnotetext{
${ }^{1}$ Brahmins, Kshatriya, and Vaishya are considered higher in status than Shudras because adolescent males from these varnas undergo a thread ceremony making them 'twice born', a privilege not available to Shudras. Brahmins are conceptualized as being at the top of the stratification system, superseding the the Kshatriyas in spite of the latter's worldly power and wealth as the ruling caste.

${ }^{2}$ See Desai (2008) for a detailed discussion on caste in 21st century India and Siddique (2011) for discrimination as a source of caste inequality in modern India.

${ }^{3}$ The survey covered all the states and union territories of India except Andaman and Nicobar and Lakshadweep, two union territories which together account for less than $0.05 \%$ of India's population.
} 
and more commonly used Indian household survey, the National Sample Survey (NSS). In particular, detailed questions on income and on social group status are asked in the IHDS, which the NSS does not include. This survey is the first, to our knowledge, which includes detailed information on incomes and on caste and religious groups after the 1931 census. Our analysis exploits the information on social groups contained in this dataset, together with information on each household's consumption expenditures and incomes.

There are forty seven consumption categories in the IHDS, which are based on the short form questions in the NSS. Thirty of the consumption categories, which are frequently purchased items, use a thirty day time frame while the other seventeen use a three hundred and sixty five day time frame. We convert all expenditures to the annual time frame before estimation. The income measure that we use in our estimations is constructed as the sum total (for each household) of wages and salaries, non-farm business income, net agricultural income, remittances, property and other income and public benefits. Each of these incomes are in turn constructed from more than fifty different sources of income queried in the IHDS.

Our estimation sample consists of 36,936 households: these are households in the IHDS where we have individual level information for household heads and for which household head is between 18 and 65 years of age. Our estimation sample has 2, 034 Brahmin households, 6, 184 high caste households, 12, 462 OBC households, 7,651 Dalit households, 3,155 Adivasi households, 4,271 Muslim households, 569 Sikh and Jain households and 610 Christian households.

There are some differences in demographic composition of households by social group, as given in table 1. While the average age of the household head varies between 43 and 47 years, Dalit and Muslim household heads are the youngest while Sikh/Jain and Christian household heads are the eldest, on average. Approximately $88 \%$ of households of all social groups have married household heads. Also, $91 \%$ of households of all social groups have male household heads, this fraction being the highest for Sikh/Jain households and lowest for Christian households. There is also some demographic variation in household size across the different social groups; while the average family size is 5.2, Muslim households have an average which is the highest at 5.8 and Christian households have an average which is the lowest, at just 4.3. There is less variation in number of adults in the household, the average number of adults across all social groups is 2.7 , with the highest average number of adults for Sikh/Jain households.

The variation in education across the different social groups is quite striking: Brahmin households 
do particularly well, with years of schooling of the household head being ten years on average; Dalit and Adivasi households do particularly badly with years of education of the household head being around four on average. OBC and Muslim households also do relatively badly with household heads having 5.6 and 4.5 years of education on average. High caste households as well as Sikh/Jain and Christian households do relatively better with more education attained by household heads (around eight years on average).

Overall household income and consumption across social groups in our sample is in line with estimates from other sources: we find household income and consumption to be the highest for Brahmin, High Caste, Sikh/Jain and Christian households, lower but similar for OBC and Muslim households and lowest for Dalit and Adivasi households. In our estimation sample we also drop all households which either report household income of more than 500,000 Rupees per year (135 households) or total household expenditure of more than 500,000 Rupees per year (92 households). Figures 1 and 2 give kernel density plots of income and consumption, for all households and selected social groups (the Brahmin and High Caste group, OBC and Muslims) in the estimation sample. Again, while Brahmin and High Caste groups have higher household income and consumption, the $\mathrm{OBC}$ and Muslim households have very similar distributions of household income and consumption.

The mean annual household income for all households in the sample is Rs. 51,000. There is a large variation in mean income across social groups, with Brahmin households having a mean income of Rs. 81,000 and Dalit households having a mean income of Rs. 38,800. The highest mean incomes are those of Brahmin households and of Sikh/Jain households. Next are mean incomes of Christian and High Caste households. OBC and Muslim households have similar mean incomes and the lowest mean incomes are those for Dalit and Adivasi households. The lowest observed income in the IHDS sample at the national level is zero for all social groups, and the highest observed income close to Rs. 500,000 for all social groups. From the percentiles of income across social groups, it is the case that OBC, Dalit, Adivasi and Muslim households all have greater mass in the left tail of the income distribution than do the other groups.

The mean household expenditures also show similar variation across the different social groups. For OBC, Dalit and Muslim households, the mean of total expenditure exceeds the mean of total household incomes. Indeed, the different households also have a substantial outstanding debt, with this debt being particularly large (as a proportion of income) for OBC households. The proportion of households that are below the poverty line is approximately 20 percent for the overall sample and highest at 41 percent for Adivasi households. It is also high for Dalit and Muslim households at 25 and 26 percent. 
Among the different consumption categories, a little more more than half of the total expenditures are spent on food. OBC households (unconditionally) spend approximately the overall average on the different consumption categories, while Muslim households spend less than the overall average on visible and other consumption and more on food than the overall average.

\subsection{Categorizing Consumption}

We are interested in items which people are quick to observe and which they associate with high income, so that such items confer status on those who consume them ('conspicuous consumption'). The classification of such items depends on the cultures, customs and norms of the society in which such items are consumed. All empirical work on conspicuous consumption in developing countries assumes that some items are conspicuous (wedding expenditures, social functions) while others are not. Rather than take this approach, we categorize the IHDS consumption items as conspicuous by carrying out a simple survey in India. The results from our survey are consistent with a categorization based on common sense.

Our categorization survey follows the recent literature that classifies items on visibility, by directly asking survey respondents whether the consumption of such items is observed and whether such items are associated with higher income (Charles et al (2009) and Heffetz (2011)). However, these surveys have been implemented in the US, where the cultures, customs and norms of the society are very different from the Indian context in which we are interested. To categorize expenditures as conspicuous, we implement a survey instrument in India which is similar as those which have been carried out in the US; the actual wording of the questions that we use is the same as used in Charles et al (2009).

Our survey instrument was implemented as an anonymous online survey; we solicited participation from 411 Masters students at the Delhi School of Economics (Department of Economics) of which 163 Masters students took the survey. The respondents were asked basic demographic information. ${ }^{4}$ They were then asked to rate lists of consumption items on visibility and association with income.

The wording of the question to identify visibility was: 'In this question we are trying to determine how easy it is to observe the amount that someone spends on each of the following consumption items. Consider a person who lives in a household and community similar to yours. Imagine that their household is not different from other similar households except that they like to, and do, consistently spend more than average on the following item. How closely would you have to interact with them in order to observe

\footnotetext{
${ }^{4} \mathrm{~A}$ summary of the demographic information is provided in appendix table A.1
} 
the consistently above average spending on each of the following consumption items?' to which the respondent could choose '1: No Interaction', '2: Occasional Interaction', '3: Friend', '4: Close Friend' or '5: No matter how much one Interacts'.

The wording of the question to identify association with income was: 'In this question we are trying to determine one's perception about the relationship between income and consumption for each of the following consumption items. Consider a randomly chosen person in society. Imagine that this person's lifetime income suddenly increased by 20 percent. For each item below, tell us how you would expect the person's spending to change' to which the respondent could choose '1: Fall', '2: Stay the same', '3: Increase by less than 20 percent', '4: Increase by 20 percent' or ' 5 : Increase by more than 20 percent'.

The list of items we used was chosen to approximate the consumption categories in the IHDS.

We categorize an item as visible if more than $20 \%$ of the respondents say they can observe consumption of the item even if they have no interaction or only occasional interaction with the person consuming the item (responses 1 or 2 to the visibility question). We categorize an item as being associated with higher income if more than $20 \%$ of the respondents say the consumption of the item would increase the same or more than an increase in income if income were to rise (responses 3 or 4 to the income question). Conspicuous consumption items are then those items which are both visible and additionally associated with higher income. All such items are given in table A.2: personal transport equipment, footwear, vacations, furniture and fixtures, social functions, repair and maintenance, house rent and rent, entertainment, clothing and bedding, jewelry and ornaments, recreation goods and personal goods. Most of these items are also ones that one would intuitively categorize as 'conspicuous consumption' and indeed there is also a great deal of correspondence to our categorization and categorizations which use similar surveys in the US. We find particularly high proportions of respondents who categorize personal transport equipment and footwear as visible while vacations, entertainment and jewelry are categorized as being associated with high incomes by around half the respondents. Very few respondents associate consumption on food at home items such as salt and spices with high income or categorize consumption on insurance premiums as visible.

Two of the items which are categorized as visible consumption (furniture and repairs) are not intuitively identifiable as visible consumption, so as a robustness check we also carry out all subsequent estimations using a measure of visible consumption that excludes the expense on these two items. We find that the main results reported in subsequent sections are robust to excluding these two expenses from our measure 
of visible consumption. ${ }^{5}$

Since our use of a 20 percent cutoff to categorize these expenditures may be considered subjective, we also construct an alternative measure of conspicuous consumption in which we add the proportions of respondents who categorize an item as visible and the proportion of respondents who categorize an item as being associated with high income. We then create weights using this sum for all items and construct our alternative measure which is the weighted sum of all consumption items, where the weights indicate the 'conspicuousness' of the item. These weights are given by

$$
\text { weight }_{k}=\frac{a_{k}+b_{k}}{\sum_{k \in K}\left(a_{k}+b_{k}\right)}
$$

where

$$
a_{k}=\% \text { respondents who categorize } k \text { as visible (responses } 1 \text { or } 2 \text { to the visibility question) }
$$

and

$b_{k}=\%$ respondents who categorize $k$ as associated with high income (responses 3 or 4 to the income question)

When we carry out all subsequent estimations using this weighted measure we find our results to be robust to the alternative categorization and measure of conspicuous consumption. ${ }^{6}$

\section{Empirical Framework}

We categorized consumption items as visible consumption with signaling value in social interactions, as described in section 3.2. We are ultimately interested in whether different social groups (defined by caste and religion) spend differentially on visible consumption. We investigate this by running simple OLS regressions on the log of spending on visible consumption items in Rupees at the household level.

The possible variables that may have an impact on visible consumption across social groups are permanent income, household assets and household demographic composition. While the latter two are easy to control for using data from the IHDS, the former is less simple.

Following a similar empirical strategy as Charles et al (2009), we begin by estimating the following baseline OLS regression:

\footnotetext{
${ }^{5}$ The estimation results with excluding these two items from visible spending measure are reported in the Appendix B and described in section 5 of the paper.

${ }^{6}$ The estimation results using this weighted alternative measure are reported in the Appendix B and described in section 5 of the paper).
} 


$$
\ln \text { Visible }_{i}=\alpha+\beta_{1} O B C_{i}+\beta_{2} \text { Dalit }_{i}+\beta_{3} \text { Adivasi }_{i}+\beta_{4} \text { Muslim }_{i}+\beta_{5} \text { SikhJain }_{i}+\beta_{6} \text { Christian }_{i}+\varepsilon_{i}
$$

where $i$ is the household. The $\beta$ coefficients on the social group dummy variables in equation (1) give us the gap in social group spending on visible consumption relative to Brahmin and Other High Caste groups. While the coefficients in (1) are important, we also want to examine how these gaps change when we control for differences in permanent income, household assets and household demographic composition.

We next include controls for current income in our baseline specification as given by (1):

$\ln$ Visible $_{i}=\alpha+\beta_{1} O B C_{i}+\beta_{2}$ Dalit $_{i}+\beta_{3}$ Adivasi $_{i}+\beta_{4}$ Muslim $_{i}+\beta_{5}$ SikhJain $_{i}+\beta_{6}$ Christian $_{i}+\varphi \ln I_{i}+\varepsilon_{i}$

where $I_{i}$ is a vector of current income, a dummy for when current income takes the value zero, the log of current income, the square of current income, the cube of current income and years of education of the household head.

Unfortunately the specification in (2) does not allow us to control directly for differences in permanent income across social groups, given the permanent income hypothesis. Since total expenditures can be used as a proxy for permanent income instead, we also estimate the following specification:

$$
\begin{array}{r}
\ln \text { Visible }_{i}=\alpha+\beta_{1} \text { OBC }_{i}+\beta_{2} \text { Dalit }_{i}+\beta_{3} \text { Adivasi }_{i}+\beta_{4} \text { Muslim }_{i}+\beta_{5} \text { SikhJain }_{i}+\beta_{6} \text { Christian }_{i}+ \\
\omega \ln \text { TotExp }_{i}+\varepsilon_{i}
\end{array}
$$

where $\operatorname{Tot} E x p_{i}$ is the total expenditure by household $i$.

The concern with using total expenditure as a proxy for permanent income is that if households make decisions on different consumptions jointly then total expenditure is potentially endogenous with expenditure on visible consumption as given in (3). Therefore we estimate a specification which instruments for total expenditure, as given by: 


$$
\begin{array}{r}
\ln \text { Visible }_{i}=\alpha+\beta_{1} O B C_{i}+\beta_{2} \text { Dalit }_{i}+\beta_{3} \text { Adivasi }_{i}+\beta_{4} \text { Muslim }_{i}+\beta_{5} \text { SikhJain }_{i}+\beta_{6} \text { Christian }_{i}+ \\
\theta \ln \widehat{\operatorname{TotE} x p_{i}}+\varepsilon_{i}
\end{array}
$$

where TotExp is instrumented by the vector of income controls, $I$ (as described in previous paragraphs). ${ }^{7}$

In the final specification, we include controls for household assets and household demographic composition as well as controls for permanent income by estimating:

$$
\begin{array}{r}
\ln \text { Visible }_{i}=\alpha+\beta_{1} \text { OBC }_{i}+\beta_{2} \text { Dalit }_{i}+\beta_{3} \text { Adivasi }_{i}+\beta_{4} \text { Muslim }_{i}+\beta_{5} \text { SikhJain }_{i}+\beta_{6} \text { Christian }_{i}+ \\
\theta \ln \widehat{\operatorname{TotE}} x p_{i}+\gamma X_{i}+\varepsilon_{i}
\end{array}
$$

where TotE $x p$ is instrumented by the vector $I$ of income controls and $X$ includes controls for household assets, gender and age of household head, household size and a dummy variable for whether the household is located in an urban area. The $\beta$ coefficients in our final specification (5) give the gaps in social group spending in visible consumption relative to Brahmin and Other High Caste groups, once we have controlled for differences in permanent income, household assets and household demographic composition.

\section{Consumption Differentials}

\subsection{Main Results}

Table 2 gives the estimation results of the regressions we specified in the previous section. In our baseline specification we find that relative to Brahmin and High Caste households, the OBC, Dalit, Adivasi and Muslim households all spend significantly less on visible consumption. Sikh and Jain households spend significantly more on visible consumption relative to Brahmin and High Caste households while Christians do not spend significantly differently.

In the next specification we add controls for current income, a dummy variable which equals one when current income takes the value zero, the log of current income, the square of current income, the cube of current income and years of education of the household head. All the gaps in visible spending relative to

\footnotetext{
${ }^{7}$ We also experiment with using years of education only as an instrument for total expenditures and we do not find that this changes our estimation results.
} 
Brahmin and High Caste groups are reduced from the baseline specification but not eliminated. We find (as in the baseline specification) that the Dalit, Adivasi and Muslim households all spend significantly less on visible consumption than Brahmin and High Caste households. OBC households also spend less but not significantly so. Sikh and Jain households as well as Christians do not spend significantly differently than Brahmin and High Caste households.

If we directly control for total expenditures in our baseline specification, we find that the gap in spending on visible consumption is reduced for all social groups. OBC households spend significantly more on visible consumption items relative to Brahmin and High Caste households. For Sikh/Jain households relative to Brahmin and High Caste households, the gap in visible spending is now negative and also statistically significant at the $5 \%$ level.

If we control for permanent income in our baseline specification we find that $\mathrm{OBC}$ households spend significantly more than Brahmin and High Caste households on visible consumption items. Dalit, Adivasi, Muslim and Sikh/Jain households spend significantly less on visible consumption items than do Brahmin and High Caste households, while Christian households do not spend significantly differently. When we control for demographic variables (gender and age of household head, household size and a dummy variable for whether the household is located in an urban area) and household assets in addition to permanent income we find that $\mathrm{OBC}$ households spend significantly more on visible consumption items than Brahmin and High Caste households but that Muslim and Sikh/Jain households spend significantly less.

Our finding that $\mathrm{OBC}$ and Muslim households in particular exhibit such differences in spending behavior is interesting given that these groups are similar along many dimensions (for instance, recall the similarity in household income and consumption distributions for these two groups as given in figures 1 and 2). The differences in spending on visible consumption between these groups can also be seen in figure 3 which plots the kernel density of the log of visible spending for all households, for Brahmin and High Caste households, for OBC households and for Muslim households. While the unconditional spending on visible consumption is highest for Brahmin and High Caste households, note that OBC households have higher visible consumption spending than Muslim households. The difference in spending across the two groups can also be seen in figure 4 which plots the Engel curves for all households, for Brahmin and High Caste households, for OBC households and for Muslim households. Engel curves are constructed by estimation of locally weighted regressions of log of visible spending on log of total expenditures, where the log of total expenditures is instrumented by the vector $I$ (as described in section 4). From figure 4, 
OBC households spend more on visible items at all levels of expenditures than Muslim households. Note also the concave shape of the Engel curves, an indication that visible consumption is a luxury good.

In table 3 we carry out the estimation to examine social group differentials on visible consumptions when we cut the estimation sample in different ways. This allows us to examine if the differential patterns that we observe across social groups are different for some sub-populations that others. We find that the higher spending of $\mathrm{OBC}$ households relative to Brahmin and High caste on visible consumption is stronger in urban rather than rural areas and when there are between one and five unmarried individuals in the household. The lower spending of Muslim households relative to Brahmin and high caste households on visible consumption is stronger in rural rather than urban areas, when the household head has less than or equal to five years of schooling and when there are more than five unmarried people in the household. There is very little variation across different ages of household head, with OBC households spending more and Muslim households spending less on visible consumption irrespective if household head is old or young.

In table 4 we also report the social group gaps in visible spending on each of the specific categories that are used to construct the overall measure of visible spending. For items with a non-trivial fraction of zero expenditures we estimate a tobit specification and report the corresponding marginal effects (personal transport, vacations, furniture, repairs, jewelry, recreation goods, personal goods, house rent and entertainment). We find that most social groups (OBC, Adivasi, Muslim and Christian) spend significantly less than Brahmin and High Caste households on footwear. The high spending of the Brahmin and High Caste groups on footwear could be due to a number of reasons. First it could due to the higher access of Brahmin and High Caste households to urban areas. Footwear (better quality shoes, etc) is more accessible in urban rather than rural areas. Infact, just $28 \%$ of the population lives in urban areas according to the 2001 Census with the majority of Adivasi, Dalit, Muslims and OBC living in rural areas. Second, footwear is more common in salaried or white collar jobs rather than in agriculture (where it is more common to go barefoot). Given the higher fraction of Brahmin and High Caste households in salaried and white collar jobs, they also tend to be the group which spends more on footwear. On the remaining items which are visible, OBC households generally spend more than Brahmin and High Caste households, and they spend significantly more on clothing, repairs, house rent and entertainment goods. Muslim households spend significantly less than Brahmin and High Caste households on social functions, clothing, recreation goods and personal goods. They spend significantly more on furniture and 
entertainment goods. The former is not very important as a signaling device, however the high spending of Muslims on entertainment is somewhat puzzling.

If $\mathrm{OBC}$ households spend more on visible consumption items and Muslim households spend less on visible consumption items, then how does their spending differ on other expenditure categories? In table 5 we give estimation results of the gaps in spending on non-visible consumptions across different social groups by running the regressions given by equation 5. For non-visible consumptions with a non-trivial number of zeros we estimate tobit specification and report the corresponding marginal effects in table 5. We find that $\mathrm{OBC}$ and Muslim households spend less on education relative to Brahmin and High Caste households, that there are no large differences in health expenditures but that OBC households spend significantly less and Muslim households significantly more on food than do Brahmin and High Caste households. These patterns can also be seen graphically in figures 5, 6 and 7, which give the Engel curves for spending on each of the non-visible consumption categories. It can be seen that Brahmin and High Caste households spend more on education at every level of expenditure than OBC households but that Muslim households spend less than OBC households on education. It can also be seen graphically that Muslim households spend more than OBC households on food expenditures, particularly at higher expenditure levels. This suggests that OBC households spend more on visible consumption by diverting spending from education and food while Muslim households spend more on food by diverting spending from education spending as well as visible consumption.

We also carry out two different robustness checks. First we use the previous definition of visible consumption but exclude expenditures on furniture and repairs. These are expenses which may not intuitively seem consistent with the definition of visible consumptions. The results when we use this measure of visible consumption is reported in table B.1. While the coefficients on our social group dummies are somewhat smaller than before the sign and significance of the coefficients is remarkably robust: we continue to find that $\mathrm{OBC}$ households spend significantly more and Muslim households significantly less on visible consumption than the Brahmin and High Caste groups. Second we use a weighted measure of visible spending where weights are assigned to all consumption goods and these weights indicate the 'conspicuousness' of the item, the results reported in table B.2 (weights are constructed as described in section 3.2). We again find that the sign and significance of our coefficients is robust to our alternative categorization of visible spending: we continue to find that $\mathrm{OBC}$ households spend significantly more and Muslim households significantly less than the Brahmin and High Caste groups. 
We next turn to the underlying mechanisms behind the gaps that we observe.

\subsection{Underlying Mechanisms}

We find that $\mathrm{OBC}$ households spend more on visible consumption than comparable Brahmin and High Caste households, and that this result is robust to excluding furniture and repairs from our measure of visible consumption or to using a weighted measure of visible consumption. We also find that Muslims, who are otherwise similar to OBC households, spend less on visible consumption than comparable Brahmin and High Caste households. Can these consumption spending patterns be explained as a means of status signaling?

Among the variables available to us, which we construct at the district level, are the mean and dispersion in incomes of households belonging to groups with distinctive social identities in the district. Using these constructed variables allows us to test implications of status signaling models such as in Glazer and Konrad (1996). ${ }^{8}$

Status signaling consumption is derived from the utility that individuals gain from status, which depends on the beliefs of others regarding their income and wealth. Others cannot observe income and wealth directly but they can easily observe conspicuous consumption. Spending by households on conspicuous consumption then depends on the income distribution of the reference group to which a household is perceived to belong to. We assume in our empirical analysis that the social group (defined by caste and religion) in ones own district is the relevant reference group. Thus, an OBC or a Muslim household's spending on conspicuous consumption will depend on the income distribution of other OBC or Muslim households in the same district.

We use groups with distinctive identities defined by caste and religious affiliations as the relevant reference group because such affiliations are visible in a variety of social interactions in India. Caste and religious affiliations prescribe customs, rules and norms of behavior. Caste and religious affiliations prescribe customs, rules and norms of behavior, including naming conventions so that such affiliations (which religion or caste a person belongs to) are visible in all non-anonymous social interactions. An example is the Yadavs in Bihar and Uttar Pradesh who belong to the OBC caste groups. Caste and religious affiliations also prescribe group specific rituals and traditions such as wearing of turbans by Sikh men, wearing beards by Muslim men, as well as rules for purity in the caste system which necessitate

\footnotetext{
${ }^{8}$ Glazer and Konrad (1996) examine status signaling by making charitable contributions, in this context we examine status signaling by spending on conspicuous consumption items.
} 
that low caste status be apparent so that such affiliations are visible in anonymous social interactions as well. The Adivasi social group is similar to Native Americans in the US or Aboriginals in Australia. They are easily identifiable due to features such as geographical isolation, simple technology and condition of living, a general backwardness to the practise of animalism, tribal language, physical features, etc.

There are several implications of status signaling consumption that we can empirically test using our data. One implication of status signaling models is that the effect of an increase in the dispersion of reference group income is theoretically ambiguous. ${ }^{9}$ An income redistribution that reduces income inequality could lead conspicuous consumption to either increase or decrease depending on the relationship between conspicuous consumption and income, which may either be concave or convex.

Another implication of such models is that if poorer people are added to the reference group then people spend more to signal status to distinguish themselves from others in this reference group. ${ }^{10}$ This suggests we should observe spending on visible consumption items which are associated with higher income to be declining in reference group income. As we show, we are able to verify this implication using our data.

In order to test these implications, we construct the mean and dispersion in income of households from the same reference group in the district $M I_{s d}$ and $D I_{s d}$ where $s$ is the social identity of the household and $d$ is the district in which the household resides. We then estimate the following OLS regressions:

$$
\begin{array}{r}
\ln \text { Visible }_{i}=\alpha+\beta_{1} \text { OBC }_{i}+\beta_{2} \text { Dalit }_{i}+\beta_{3} \text { Adivasi }_{i}+ \\
\beta_{4} \text { Muslim }_{i}+\beta_{5} \text { SikhJain }_{i}+\beta_{6} \text { Christian }_{i}+ \\
\theta \ln \text { TotExp } \\
i
\end{array}
$$

We find the implications of the status signaling models are satisfied using the IHDS data. The results are reported in table 6 . We find the coefficient on mean income of own reference group to be negative and significant, as implied by status signaling models. This is the case when we only include mean income of own reference group and when we include dispersion in this income as well as mean income of own reference group. ${ }^{11}$

\footnotetext{
${ }^{9}$ This is Property 3 characterizing the revealing equilibrium of the model given in Glazer and Konrad (1996).

${ }^{10}$ This is Property 4 characterizing the revealing equilibrium of the model given in Glazer and Konrad (1996).

${ }^{11}$ For some districts the poorest Brahmin and High Caste households sometimes have lower income than the poorest households from other social groups. This could also be driving our result concerning Muslim households since the poorest Muslim household may still have higher income than the poorest Brahmin/High Caste household in the district. In order to check whether this is the case we drop Brahmin and High Caste households which are poorer than the poorest member of all other social groups within the same district. We then re-estimate all the specifications for this reduced sample from
} 
We also test the prediction of status signaling models, that visible spending should be declining in reference group income within each group with a distinctive social identity, by running a set of regressions reported in table 7 . We find that we satisfy this prediction for each of the groups except for Sikh/Jains and Christians where there is either a negative insignificant relationship between visible spending and mean income of reference group or a positive insignificant relationship. The likely explanation for this is that there are few Sikh/Jain and Christian households in our sample and moreover their geographical dispersion across India is concentrated in just a few regions. When we include dispersion in income of reference group as well as mean income in (II), the negative and significant relation between conspicuous consumption and mean income of reference group persists. This shows, for instance, that Brahmin and High Caste households in districts where the average Brahmin and High Caste income is high spend less on visible consumption than Brahmin and High Caste households in districts where the average Brahmin and High Caste income is low. The coefficient on dispersion in reference group income is positive and significant for Brahmin and High Caste as well as OBC but insignificant for all other social groups. The difference in the coefficient on dispersion of income across groups suggests that the relationship between income and visible consumption also varies across social groups.

We find that controlling for reference group income does not reduce the social group gap in visible spending for all groups, reducing it for OBC and Sikh/Jain but increasing it for Dalit and Muslim households. We take this as evidence that while there is status signaling associated with spending on visible consumption items, there are also other factors which have a strong impact on social group spending on visible consumption items which we are unable to control for. We consider the following alternative mechanisms which stem from religious observance: dietary requirements, Sanskritization and the practise of purdah/ghungat.

Within the Hindu religion there are specific diet requirements (vegetarianism). Since eating meat is considered polluting, its consumption is lower among high status caste groups. This particular diet requirement does not hold for Muslim households so consumption of meat is also likely to be higher among Muslims than among High Caste Hindus. This is the case in the IHDS data: just 24\% of Brahmin, $55 \%$ of High Caste and $57 \%$ of OBC eat meat while as many as $88 \%$ of Muslims do so (see Appendix Table

which we also exclude Sikh/Jain and Christian households since there are only a small number of such households in our sample. We find without the inclusion of reference group income characteristics the estimation results are almost identical to those corresponding to specification 5 reported in Table 2 of the paper so the reduced sample does not have an impact on the baseline results. When we add reference group income characteristics to this sample we continue to find that Muslim households spend significantly less on visible consumption than comparable Brahmin and High Caste. These results are available from the authors on request. 
1 in Desai (2008)). In order to examine whether different diet requirements drive our results on food spending, we estimate and report regressions in which the outcome variable is spending on food excluding expenditures on meat. The results are reported in Table 5. We continue to find that Muslim households spend significantly more and OBC households less on non-meat food items than do comparable Brahmin and High Caste households so our results are not driven by differences in dietary requirements across social groups.

Sanskritization is a process by which low caste groups emulate the customs and rites of high caste groups to acquire the social status of the latter, first described by Srinivas (1956). According to Srinivas (1956), this process is particularly likely to take place in the middle regions of the hierarchy defined by the caste system. The OBC satisfy the definition of being in the middle of the caste hierarchy, unlike the Dalit groups which are far below the Brahmin and High Caste groups. They are also a dominant force in Indian Politics since 1990. By spending more on status consumption compared to other groups, OBCs emulate the Brahmin and High Castes. If it is Sanskritization that drives our results, then it explains why we don't observe high spending on status by Dalits as well as why we don't observe high spending on status consumption by non-Hindu social groups such as Muslims. Additional tests of whether and to what extent Sanskritization processes explain consumption differences across social groups is an important question for future research.

Another explanation for the low spending of the Muslim households on status consumption could stem from the religious observance of modesty and particularly the practise of purdah. The purdah or veil/seclusion for Muslim women would explain the low spending of Muslim households on clothing expenditures. A similar practise among Hindu households is known as ghunghat. However, higher fractions of Muslims practise purdah than Hindus practise ghungat. Within the IHDS sample itself, there are $63 \%$ of Brahmin, $47 \%$ of High Caste, and $52 \%$ of OBC who practise ghungat, while as many as $84 \%$ of Muslim households practise purdah (see Appendix Table 1 in Desai (2008)). The stronger norms against flashy spending among Muslim households in comparison to other social groups could explain our findings on the low spending of Muslim households relative to other social groups.

\section{Conclusion}

We study consumption spending on items which have signaling value in social interactions across different social groups in India. We find that there are important differences in such spending across 
groups, in particular we find that OBC households spend significantly more and Muslim households spend significantly less on visible consumption than comparable Brahmin and high caste households. Some of these gaps can be explained as a result of the status signaling nature of these consumptions. We find that the implications of status signaling models hold in our data, in that spending on visible consumption items is declining in the mean income of own reference group within each social group. However, we continue to find gaps in visible spending across social groups even after we control for reference group characteristics, which indicates the importance of alternative mechanisms which stem from religious observance such as Sanskritization or emulation of high caste groups by the low caste OBC.

There are important implications of our results for policy: we have shown that status signaling spending may be quite large among groups which are relatively poor and that people are myopic, driven by norms and signaling. Giving cash transfers/cash benefits to these groups might not lead to spending on education and health but also on visible consumption. So, for this context, vouchers may be preferable to cash transfers.

In future work and extensions of this paper we intend to investigate more the underlying mechanisms which result in persistent differences across groups in spending on visible consumption and the impacts of such differences on well-being, wealth and savings. 


\section{References}

[1] Akerlof, George A. and Rachel E. Kranton, 2000. Economics and Identity. Quarterly Journal of Economics, 115(3): 715-753.

[2] Bagwell, Laurie Simon, and B. Douglas Bernheim, 1996. Veblen Effects in a Theory of Conspicuous Consumption. American Economic Review, 86: 349-373.

[3] Banerjee, Abhijit V., 1992. A Simple Model of Herd Behavior. Quarterly Journal of Economics. 107(3): 797-817.

[4] Banerjee, Abhijit V. and Esther Duflo, 2006. The Economic Lives of the Poor. Journal of Economic Perspectives, 21(1): 141-167.

[5] Bloch, Francis, Vijayendra Rao and Sonalde Desai, 2004. Wedding Celebrations as Conspicuous Consumption: Signaling Social Status in Rural India. The Journal of Human Resources, Vol. XXXIX, Issue 3.

[6] Basu, Kaushik, 1989. A Theory of Association: Social Status, Prices and Markets. Oxford Economic Papers, 41(4): 653-71.

[7] Charles, Kerwin Kofi, Erik Hurst and Nikolai Roussanov, 2009. Conspicuous Consumption and Race. Quarterly Journal of Economics, Vol. CXXIV, Issue 2.

[8] Desai, Sonalde, 2008. Caste in 21st Century India: Competing Narratives. India Human Development Survey Working Paper No. 12.

[9] Desai, Sonalde, Amaresh Dubey, B.L. Joshi, Mitali Sen, Abusaleh Shariff and Reeve Vanneman. India Human Development Survey: Design and Data Quality. India Human Development Survey Technical Paper No.1.

[10] Eswaran, M., B. Ramaswami and W. Wadhwa. 2009. Status, Caste, and the Time Allocation of Women in Rural India. Working Paper.

[11] Frank, R.H., 2005. Positional Externalities cause large and preventable welfare losses. American Economic Review Papers and Proceedings. 95(2): 137-141. 
[12] Glazer, Amihai and Kai Konrad, 1996. A Signaling Explanation for Charity. American Economic Review. 86(4): 1019-1028.

[13] Harriger, Jessica, Neha Khanna and Andreas Pape, 2010. Conspicuous Consumption and Inequality. Working paper.

[14] Heffetz, Ori, 2011. A Test of Conspicuous Consumption: Visibility and Income Elasticities. Review of Economics and Statistics. 93.4: 1101-1117.

[15] Hoff, Karla, Mayuresh Kshetramade and Ernst Fehr, 2009. Caste and Punishment: The Legacy of Caste Culture in Norm Enforcement. IZA DP No.4343.

[16] Ireland, Norman, 1994. On Limiting the Market for Status Signals. Journal of Public Economics. 53: 91-110.

[17] Kuhn, Peter, Peter Kooreman, Adriann R. Soetevent and Arie Kapteyn, 2011. The Effects of Lottery Prizes on Winners and their Neighbors: Evidence from the Dutch Postcode Lottery. American Economic Review, 101 (5).

[18] Moav, Omer and Zvika Neeman, 2008. Conspicuous Consumption, Human Capital, and Poverty. CEPR DP 6864.

[19] Ravina, Enrichetta, 2007. Habit Persistence and Keeping Up with the Joneses: Evidence from Micro Data. Working Paper.

[20] Siddique, Zahra, 2011. Evidence on Caste-Based Discrimination. Labour Economics, 2011, 18 (S1), S146-S159.

[21] Srinivas, M. N., 1956. A Note on Sanskritization and Westernization. The Far Eastern Quarterly, 15(4): 481-496.

[22] Van Wessel, Margit, 2004. Talking About Consumption: How an Indian Middle Class Dissociates from Middle-Class Life. Culture Dynamics, 16(1), 93-116

[23] Veblen, Thorstein, 1899. The Theory of the Leisure Class. New York: Macmillan, New York. 


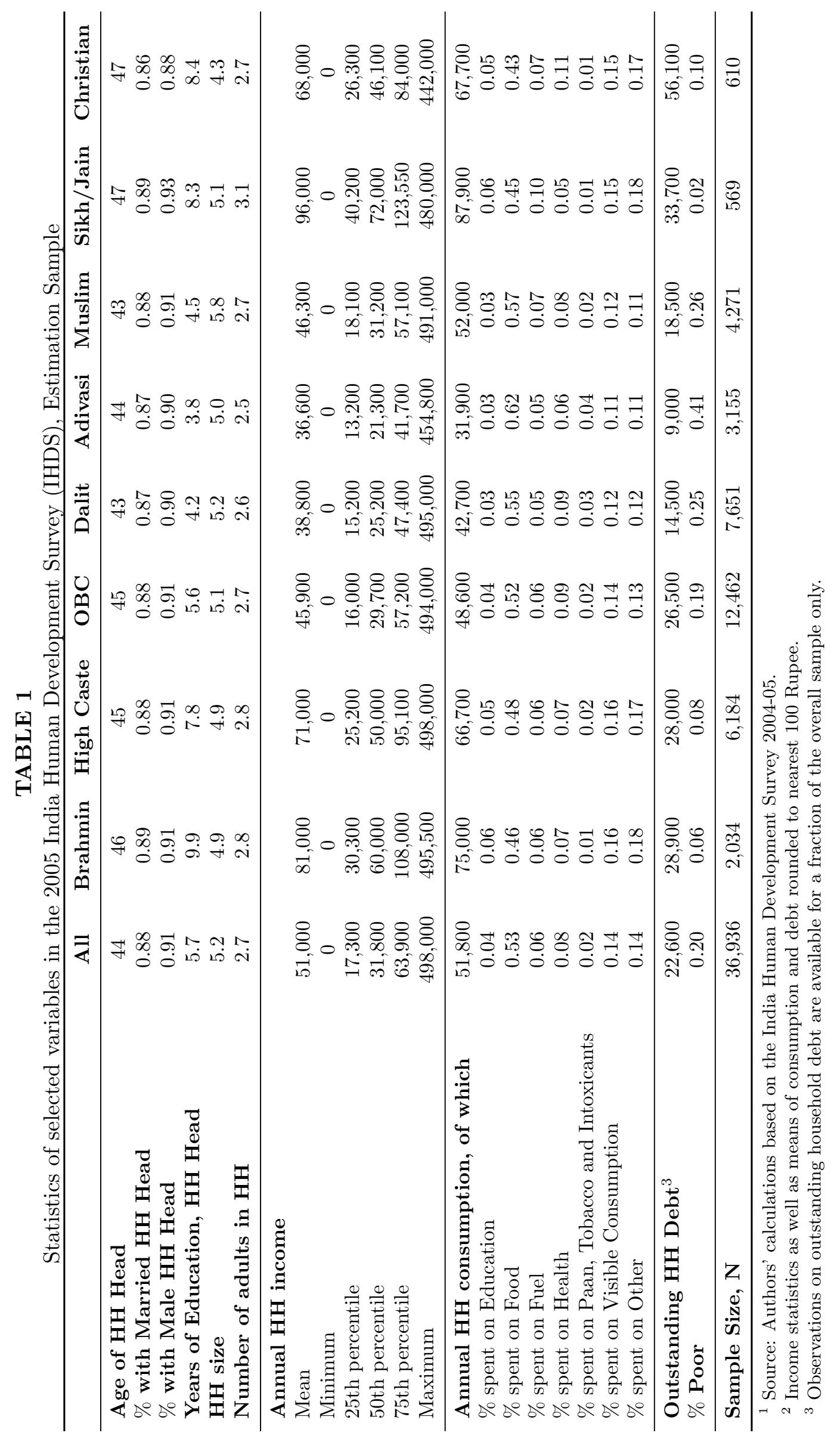


TABLE 2

Estimated Other Social Group-Brahmin/High Caste Gap in Log Visible Expenditure

\begin{tabular}{lcccccc}
\hline Regression Controls Included & OBC & Dalit & Adivasi & Muslim & Sikh/Jain & Christian \\
\hline (1) No additional controls & $-0.40^{* * *}$ & $-0.73^{* * *}$ & $-1.24^{* * *}$ & $-0.53^{* * *}$ & $0.32^{* * *}$ & -0.11 \\
& $(0.02)$ & $(0.02)$ & $(0.04)$ & $(0.03)$ & $(0.06)$ & $(0.06)$ \\
(2) Controls for Income & -0.03 & $-0.23^{* * *}$ & $-0.67^{* * *}$ & $-0.14^{* * *}$ & 0.07 & -0.07 \\
& $(0.02)$ & $(0.02)$ & $(0.04)$ & $(0.03)$ & $(0.06)$ & $(0.05)$ \\
(3) Controls for Total Expenditure & $0.04^{* *}$ & $-0.08^{* * *}$ & $-0.14^{* * *}$ & $-0.19^{* * *}$ & $-0.14^{* * *}$ & -0.05 \\
& $(0.02)$ & $(0.02)$ & $(0.03)$ & $(0.02)$ & $(0.05)$ & $(0.04)$ \\
(4) Instrumenting for Total & $0.06^{* * *}$ & $-0.05^{* *}$ & $-0.08^{* * *}$ & $-0.17^{* * *}$ & $-0.16^{* * *}$ & -0.05 \\
Expenditure using Income & $(0.02)$ & $(0.02)$ & $(0.03)$ & $(0.02)$ & $(0.05)$ & $(0.04)$ \\
(5) Specification (4) plus & $0.08^{* * *}$ & -0.03 & -0.06 & $-0.14^{* * *}$ & $-0.17^{* * *}$ & -0.07 \\
demographic and other controls & $(0.02)$ & $(0.02)$ & $(0.03)$ & $(0.02)$ & $(0.05)$ & $(0.05)$ \\
\hline
\end{tabular}

${ }^{1}$ Source: Authors' calculations based on the India Human Development Survey 2004-05, estimation sample as described in the paper.

${ }^{2}$ Heteroscedasticity corrected robust standard errors reported in brackets.

$3 *$ significant at $5 \%, * *$ significant at $2.5 \%, * * *$ significant at $1 \%$

${ }^{4}$ Base Group: Brahmin and Other High Caste combined.

${ }^{5}$ Specification (1) includes only social group dummies in a regression on $\ln$ (Visible Spending). Specification (2) estimates (1) with the addition of controls for Current Income, $\ln$ (Current Income), the square of current income, the cube of current income, a dummy variable which takes the value one when Current Income is equal to zero and years of education. Specification (3) estimates (1) with the addition of controls for $\ln$ (Total Expenditure). Specification (4) estimates (1) with the addition of instruments for $\ln$ (Total Expenditure); instruments include Current Income, $\ln$ (Current Income), the square of current income, the cube of current income, a dummy variable which takes the value one when Current Income is equal to zero and years of education. Specification (5) estimates (4) with the addition of controls for household assets, gender and age of household head, household size and a dummy variable for whether the household is located in an urban area. 
TABLE 3

Estimated Other Social Group-Brahmin/High Caste Gap in Log Visible Expenditure, Specific Sub-samples

\begin{tabular}{|c|c|c|c|c|c|c|}
\hline Sub-sample & $\mathrm{OBC}$ & Dalit & Adivasi & Muslim & Sikh/Jain & Christian \\
\hline $\begin{array}{l}\text { (1) Place of Residence } \\
\text { (a) Rural } \\
(N=23,417) \\
\text { (b) Urban } \\
(N=13,519)\end{array}$ & $\begin{array}{c}0.05^{*} \\
(0.02) \\
0.13^{* * *} \\
(0.02)\end{array}$ & $\begin{array}{c}-0.05^{*} \\
(0.02) \\
0.00 \\
(0.03)\end{array}$ & $\begin{array}{c}-0.08^{*} \\
(0.04) \\
-0.18^{* *} \\
(0.08)\end{array}$ & $\begin{array}{c}-0.21^{* * *} \\
(0.03) \\
-0.01 \\
(0.03)\end{array}$ & $\begin{array}{c}-0.13^{* *} \\
(0.05) \\
-0.18^{* *} \\
(0.08)\end{array}$ & $\begin{array}{c}-0.16^{* *} \\
(0.07) \\
0.05 \\
(0.05)\end{array}$ \\
\hline $\begin{array}{l}\text { (2) Education of HH Head } \\
\text { (a) years of Education } \leq 5 \text { years } \\
(N=18,885) \\
\text { (b) years of Education }>5 \text { and } \leq 10 \text { years } \\
(N=12,360) \\
\text { (c) years of Education }>10 \text { years } \\
(N=5,691)\end{array}$ & $\begin{array}{c}0.08^{* *} \\
(0.03) \\
0.04 \\
(0.03) \\
0.12^{* * *} \\
(0.03) \\
\end{array}$ & $\begin{array}{c}-0.05 \\
(0.03) \\
-0.04^{*} \\
(0.03) \\
0.01 \\
(0.04) \\
\end{array}$ & $\begin{array}{c}-0.11 \\
(0.06) \\
0.00 \\
(0.04) \\
-0.13 \\
(0.10) \\
\end{array}$ & $\begin{array}{c}-0.18^{* * *} \\
(0.04) \\
-0.11^{* * *} \\
(0.03) \\
-0.01 \\
(0.05) \\
\end{array}$ & $\begin{array}{c}-0.07 \\
(0.09) \\
-0.18^{* * *} \\
(0.06) \\
-0.23^{* *} \\
(0.10) \\
\end{array}$ & $\begin{array}{c}-0.03 \\
(0.09) \\
-0.15^{*} \\
(0.07) \\
0.07 \\
(0.07) \\
\end{array}$ \\
\hline $\begin{array}{l}\text { (3) Age of } \mathrm{HH} \text { Head } \\
\text { (a) age between } 18 \text { and } \leq 45 \text { years } \\
(N=20,826) \\
\text { (b) age }>45 \text { years } \\
(N=16,110)\end{array}$ & $\begin{array}{c}0.08^{* * *} \\
(0.02) \\
0.06^{* *} \\
(0.03)\end{array}$ & $\begin{array}{l}-0.03 \\
(0.02) \\
-0.03 \\
(0.03)\end{array}$ & $\begin{array}{c}0.00 \\
(0.04) \\
-0.15^{* * *} \\
(0.06)\end{array}$ & $\begin{array}{c}-0.14^{* * *} \\
(0.03) \\
-0.14^{* * *} \\
(0.04)\end{array}$ & $\begin{array}{c}-0.18^{* * *} \\
(0.06) \\
-0.15^{*} \\
(0.07)\end{array}$ & $\begin{array}{l}-0.05 \\
(0.07) \\
-0.09 \\
(0.06)\end{array}$ \\
\hline $\begin{array}{l}\text { (4) } \text { HH Size } \\
\text { (a) }<10 \text { people } \\
(N=35,189) \\
\text { (b) } \geq 10 \text { people } \\
(N=1,747)\end{array}$ & $\begin{array}{c}0.09^{* * *} \\
(0.02) \\
-0.13 \\
(0.08) \\
\end{array}$ & $\begin{array}{l}-0.02 \\
(0.02) \\
-0.12 \\
(0.08) \\
\end{array}$ & $\begin{array}{c}0.06 \\
(0.03) \\
-0.02 \\
(0.13) \\
\end{array}$ & $\begin{array}{c}-0.13^{* * *} \\
(0.02) \\
-0.25^{* * *} \\
(0.09) \\
\end{array}$ & $\begin{array}{c}-0.16^{* * *} \\
(0.05) \\
-0.09 \\
(0.13) \\
\end{array}$ & $\begin{array}{l}-0.06 \\
(0.05) \\
-0.13 \\
(0.26) \\
\end{array}$ \\
\hline $\begin{array}{l}\text { (5) Married people in the } \mathrm{HH} \\
\text { (a) No unmarried } \\
(N=2,202) \\
\text { (b) }>0 \text { and }<5 \text { unmarried } \\
(N=29,384) \\
(\text { c) } \geq 5 \text { unmarried } \\
(N=5,350)\end{array}$ & $\begin{array}{c}0.06 \\
(0.07) \\
0.09^{* * *} \\
(0.02) \\
-0.01 \\
(0.05)\end{array}$ & $\begin{array}{l}0.01 \\
(0.10) \\
-0.03 \\
(0.02) \\
-0.09 \\
(0.05)\end{array}$ & $\begin{array}{c}-0.45^{* *} \\
(0.19) \\
-0.02 \\
(0.03) \\
-0.03 \\
(0.08)\end{array}$ & $\begin{array}{c}0.01 \\
(0.09) \\
-0.12^{* * *} \\
(0.03) \\
-0.26^{* * *} \\
(0.05)\end{array}$ & $\begin{array}{c}-0.32 \\
(0.28) \\
-0.14^{* * *} \\
(0.05) \\
-0.19 \\
(0.10)\end{array}$ & $\begin{array}{l}-0.21 \\
(0.25) \\
-0.05 \\
(0.05) \\
-0.19 \\
(0.21)\end{array}$ \\
\hline
\end{tabular}




\section{TABLE 4}

Estimated Other Social Group-Brahmin/High Caste Gap in Log Visible Expenditure, Specific Items

\begin{tabular}{|c|c|c|c|c|c|c|}
\hline Dependent Variable & $\mathrm{OBC}$ & Dalit & Adivasi & Muslim & Sikh/Jain & Christian \\
\hline (1) $\ln$ (Footwear) & $\begin{array}{c}-0.19^{* * *} \\
(0.03)\end{array}$ & $\begin{array}{l}-0.06 \\
(0.03)\end{array}$ & $\begin{array}{c}-0.16^{* * *} \\
(0.05)\end{array}$ & $\begin{array}{c}-0.14^{* * *} \\
(0.04)\end{array}$ & $\begin{array}{c}0.05 \\
(0.06)\end{array}$ & $\begin{array}{c}-0.20^{* * *} \\
(0.07)\end{array}$ \\
\hline (2) $\ln$ (Social Functions) & $\begin{array}{c}0.06 \\
(0.05)\end{array}$ & $\begin{array}{c}-0.14^{* *} \\
(0.06)\end{array}$ & $\begin{array}{c}-0.43^{* * *} \\
(0.08)\end{array}$ & $\begin{array}{c}-0.41^{* * *} \\
(0.07)\end{array}$ & $\begin{array}{c}0.11 \\
(0.12)\end{array}$ & $\begin{array}{c}-0.31^{* *} \\
(0.13)\end{array}$ \\
\hline (3) $\ln$ (Clothing) & $\begin{array}{l}0.07^{* *} \\
(0.03)\end{array}$ & $\begin{array}{c}0.04 \\
(0.04)\end{array}$ & $\begin{array}{c}-0.22^{* * *} \\
(0.05)\end{array}$ & $\begin{array}{c}-0.14^{* * *} \\
(0.04)\end{array}$ & $\begin{array}{l}-0.09 \\
(0.08)\end{array}$ & $\begin{array}{l}-0.12 \\
(0.10)\end{array}$ \\
\hline (4) $\ln$ (Personal Transport) & $\begin{array}{c}0.06 \\
(0.06)\end{array}$ & $\begin{array}{l}-0.07 \\
(0.07)\end{array}$ & $\begin{array}{c}0.07 \\
(0.10)\end{array}$ & $\begin{array}{l}-0.12 \\
(0.07)\end{array}$ & $\begin{array}{c}1.12^{* * *} \\
(0.17)\end{array}$ & $\begin{array}{c}-1.03^{* * *} \\
(0.09)\end{array}$ \\
\hline (5) $\ln$ (Vacations) & $\begin{array}{l}-0.04 \\
(0.04)\end{array}$ & $\begin{array}{l}-0.09 \\
(0.05)\end{array}$ & $\begin{array}{c}0.42^{* * *} \\
(0.10)\end{array}$ & $\begin{array}{l}-0.08 \\
(0.05)\end{array}$ & $\begin{array}{c}-0.46^{* * *} \\
(0.07)\end{array}$ & $\begin{array}{c}-0.48^{* * *} \\
(0.05)\end{array}$ \\
\hline (6) $\ln$ (Furniture) & $\begin{array}{c}0.05 \\
(0.04)\end{array}$ & $\begin{array}{l}-0.06 \\
(0.04)\end{array}$ & $\begin{array}{c}0.56^{* * *} \\
(0.09)\end{array}$ & $\begin{array}{c}0.18^{* * *} \\
(0.05)\end{array}$ & $\begin{array}{c}-0.22^{* * *} \\
(0.06)\end{array}$ & $\begin{array}{c}0.49^{* * *} \\
(0.14)\end{array}$ \\
\hline (7) $\ln$ (Repairs) & $\begin{array}{c}0.43^{* * *} \\
(0.08)\end{array}$ & $\begin{array}{l}-0.08 \\
(0.07)\end{array}$ & $\begin{array}{c}0.03 \\
(0.11)\end{array}$ & $\begin{array}{l}-0.05 \\
(0.08)\end{array}$ & $\begin{array}{c}-0.46^{* * *} \\
(0.14)\end{array}$ & $\begin{array}{l}-0.01 \\
(0.19)\end{array}$ \\
\hline (8) $\ln ($ Jewelry) & $\begin{array}{l}-0.06 \\
(0.04)\end{array}$ & $\begin{array}{l}-0.03 \\
(0.05)\end{array}$ & $\begin{array}{c}0.13 \\
(0.10)\end{array}$ & $\begin{array}{l}-0.10 \\
(0.05)\end{array}$ & $\begin{array}{c}-0.30^{* * *} \\
(0.08)\end{array}$ & $\begin{array}{c}-0.34^{* * *} \\
(0.08)\end{array}$ \\
\hline (9) $\ln$ (Recreation Goods) & $\begin{array}{l}-0.04 \\
(0.03)\end{array}$ & $\begin{array}{c}-0.08^{* * *} \\
(0.03)\end{array}$ & $\begin{array}{c}-0.08^{*} \\
(0.04)\end{array}$ & $\begin{array}{c}-0.11^{* * *} \\
(0.03)\end{array}$ & $\begin{array}{c}-0.23^{* * *} \\
(0.04)\end{array}$ & $\begin{array}{c}-0.21^{* * *} \\
(0.04)\end{array}$ \\
\hline (10) $\ln$ (Personal Goods) & $\begin{array}{l}-0.10 \\
(0.05)\end{array}$ & $\begin{array}{c}-0.26^{* * *} \\
(0.06)\end{array}$ & $\begin{array}{c}-0.38^{* * *} \\
(0.07)\end{array}$ & $\begin{array}{c}-0.13^{*} \\
(0.06)\end{array}$ & $\begin{array}{c}-0.44^{* * *} \\
(0.11)\end{array}$ & $\begin{array}{c}-0.61^{* * *} \\
(0.10)\end{array}$ \\
\hline (11) $\ln ($ House Rent $)$ & $\begin{array}{c}0.09^{* * *} \\
(0.02)\end{array}$ & $\begin{array}{c}-0.06^{*} \\
(0.03)\end{array}$ & $\begin{array}{l}-0.02 \\
(0.06)\end{array}$ & $\begin{array}{c}0.02 \\
(0.03)\end{array}$ & $\begin{array}{c}-0.15^{* * *} \\
(0.04)\end{array}$ & $\begin{array}{c}0.01 \\
(0.06)\end{array}$ \\
\hline (12) $\ln$ (Entertainment) & $\begin{array}{c}0.17^{* * *} \\
(0.05)\end{array}$ & $\begin{array}{c}0.31^{* * *} \\
(0.06)\end{array}$ & $\begin{array}{c}0.33^{* * *} \\
(0.10)\end{array}$ & $\begin{array}{l}0.13^{* *} \\
(0.06)\end{array}$ & $\begin{array}{c}-0.35^{* * *} \\
(0.05)\end{array}$ & $\begin{array}{c}0.41^{* * *} \\
(0.17)\end{array}$ \\
\hline
\end{tabular}

${ }^{1}$ Source: Authors' calculations based on the India Human Development Survey 2004-05, estimation sample as described in the paper.

${ }^{2}$ Heteroscedasticity corrected robust standard errors are reported in brackets.

$3 *$ significant at $5 \%, * *$ significant at $2.5 \%, * * *$ significant at $1 \%$

${ }^{4}$ Base Group: Brahmin and Other High Caste combined.

${ }^{5}$ Every regression for item (1)-(3) uses specification (5) in table 2 for the given dependent variable. Every regression for item (4)-(12) estimates the corresponding IV Tobit specification and reports the marginal effect for items which have a non-trivial number of zeroes. 


\section{TABLE 5}

Estimated Other Social Group-Brahmin/High Caste Gap in Log Visible Expenditure, non-visible Expenditures

\begin{tabular}{lcccccc}
\hline Dependent Variable & OBC & Dalit & Adivasi & Muslim & Sikh/Jain & Christian \\
\hline (1) $\ln ($ Food) & $-0.03^{* * *}$ & $-0.01^{*}$ & -0.01 & $0.06^{* * *}$ & $0.07^{* * *}$ & $-0.11^{* * *}$ \\
& $(0.01)$ & $(0.01)$ & $(0.01)$ & $(0.01)$ & $(0.01)$ & $(0.02)$ \\
(1a) $\ln$ (Food, excluding meat) & $-0.03^{* * *}$ & $-0.02^{* *}$ & -0.02 & $0.06^{* * *}$ & $0.07^{* * *}$ & $-0.12^{* * *}$ \\
& $(0.01)$ & $(0.01)$ & $(0.01)$ & $(0.01)$ & $(0.01)$ & $(0.02)$ \\
\hline (2) $\ln$ (Education) & $-0.31^{* * *}$ & $-0.31^{* * *}$ & $-0.59^{* * *}$ & $-1.11^{* * *}$ & -0.32 & 0.07 \\
& $(0.08)$ & $(0.09)$ & $(0.13)$ & $(0.08)$ & $(0.19)$ & $(0.20)$ \\
(3) $\ln$ (Health) & 0.06 & 0.13 & $-1.89^{* * *}$ & 0.02 & -0.01 & $0.92^{* * *}$ \\
& $(0.09)$ & $(0.11)$ & $(0.14)$ & $(0.13)$ & $(0.25)$ & $(0.26)$ \\
\hline
\end{tabular}

${ }^{1}$ Source: Authors' calculations based on the India Human Development Survey 2004-05, estimation sample as described in the paper.

${ }^{2}$ Heteroscedasticity corrected robust standard errors are reported in brackets.

$3 *$ significant at $5 \%, * *$ significant at $2.5 \%, * * *$ significant at $1 \%$

${ }^{4}$ Base Group: Brahmin and Other High Caste combined.

${ }^{5}$ The regression for (1) and (1a) uses specification (5) in table 2 for the given dependent variable. Regression for (2)-(3) estimates the corresponding IV Tobit specification and reports the marginal effect for items which have a non-trivial number of zeroes. 


\section{TABLE 6}

Estimated Other Social Group-Brahmin/High Caste Gap in Log Visible Expenditure, District level controls

\begin{tabular}{lcc}
\hline Variable & $(\mathrm{I})$ & $(\mathrm{II})$ \\
\hline OBC & 0.03 & 0.02 \\
& $(0.02)$ & $(0.02)$ \\
Dalit & $-0.10^{* * *}$ & $-0.10^{* * *}$ \\
& $(0.02)$ & $(0.02)$ \\
Adivasi & $-0.11^{* * *}$ & $-0.11^{* * *}$ \\
& $(0.03)$ & $(0.03)$ \\
Muslim & $-0.19^{* * *}$ & $-0.20^{* * *}$ \\
& $(0.02)$ & $(0.02)$ \\
Sikh/Jain & $-0.15^{* * *}$ & $-0.15^{* * *}$ \\
& $(0.05)$ & $(0.05)$ \\
Christian & -0.05 & -0.06 \\
& $(0.05)$ & $(0.05)$ \\
$\ln \left(M I_{S D}\right)$ & $-0.16^{* * *}$ & $-0.18^{* * *}$ \\
& $(0.02)$ & $(0.02)$ \\
$D I_{S D}$ & & $0.07^{* * *}$ \\
& & $(0.02)$ \\
\hline
\end{tabular}

${ }^{1}$ Source: Authors' calculations based on the India Human Development Survey 2004-05, estimation sample as described in the paper.

${ }^{2}$ Heteroscedasticity corrected robust standard errors are reported in brackets.

$3 *$ significant at $5 \%, * *$ significant at $2.5 \%, * * *$ significant at $1 \%$

${ }^{4}$ Base Group: Brahmin and Other High Caste combined.

${ }^{5}$ Specification (I) estimates specification (5) in table 2 with the addition of mean income of own social group in the district. Specification (II) estimates specification (5) in table 2 with the addition of mean income of own social group in the district and also the dispersion in income of own social group in the district. 


\section{TABLE 7}

Estimated variation in Log Visible Expenditure with mean income of reference group, each social group

\begin{tabular}{lccc}
\hline \multirow{2}{*}{ Social Group } & (I) & & (II) \\
& $\begin{array}{c}\text { Coefficient on Mean } \\
\text { Income of Reference Group }\end{array}$ & $\begin{array}{c}\text { Coefficient on Mean } \\
\text { Income of Reference Group }\end{array}$ & $\begin{array}{c}\text { Coefficient on Dispersion in } \\
\text { Income of Reference Group }\end{array}$ \\
\hline Brahmin and High Caste & $-0.09^{* * *}$ & $-0.11^{* * *}$ & $0.15^{* * *}$ \\
& $(0.03)$ & $(0.03)$ & $(0.03)$ \\
OBC & $-0.13^{* * *}$ & $-0.14^{* * *}$ & $0.08^{* *}$ \\
& $(0.03)$ & $(0.03)$ & $(0.03)$ \\
Dalit & $-0.23^{* * *}$ & $-0.23^{* * *}$ & -0.04 \\
& $(0.04)$ & $(0.04)$ & $(0.05)$ \\
Adivasi & $-0.30^{* * *}$ & $-0.32^{* * *}$ & 0.04 \\
& $(0.06)$ & $(0.06)$ & $(0.06)$ \\
Muslim & $-0.12^{* * *}$ & $-0.14^{* * *}$ & 0.04 \\
& $(0.04)$ & $(0.05)$ & $(0.05)$ \\
Sikh/Jain & -0.07 & -0.24 & 0.28 \\
Christian & $(0.18)$ & $(0.21)$ & $(0.15)$ \\
& 0.11 & $0.22^{*}$ & $-0.37^{* * *}$ \\
\hline
\end{tabular}

${ }^{1}$ Source: Authors' calculations based on the India Human Development Survey 2004-05, estimation sample as described in the paper.

2 Heteroscedasticity corrected robust standard errors are reported in brackets.

$3 *$ significant at $5 \%, * *$ significant at $2.5 \%, * * *$ significant at $1 \%$

${ }^{4}$ In (I), every coefficient is based on a separate regression estimated on the sub-sample of the given social group, where the specification is the same as specification (5) in table 2 with the inclusion of mean income of own social group in the district. In (II), every coefficient is based on a separate regression estimated on the sub-sample of the given social group, where the specification is the same as specification (5) in table 2 with the inclusion of mean income and dispersion in income of own social group in the district. 
Figure 1

Distribution of Income, selected social groups

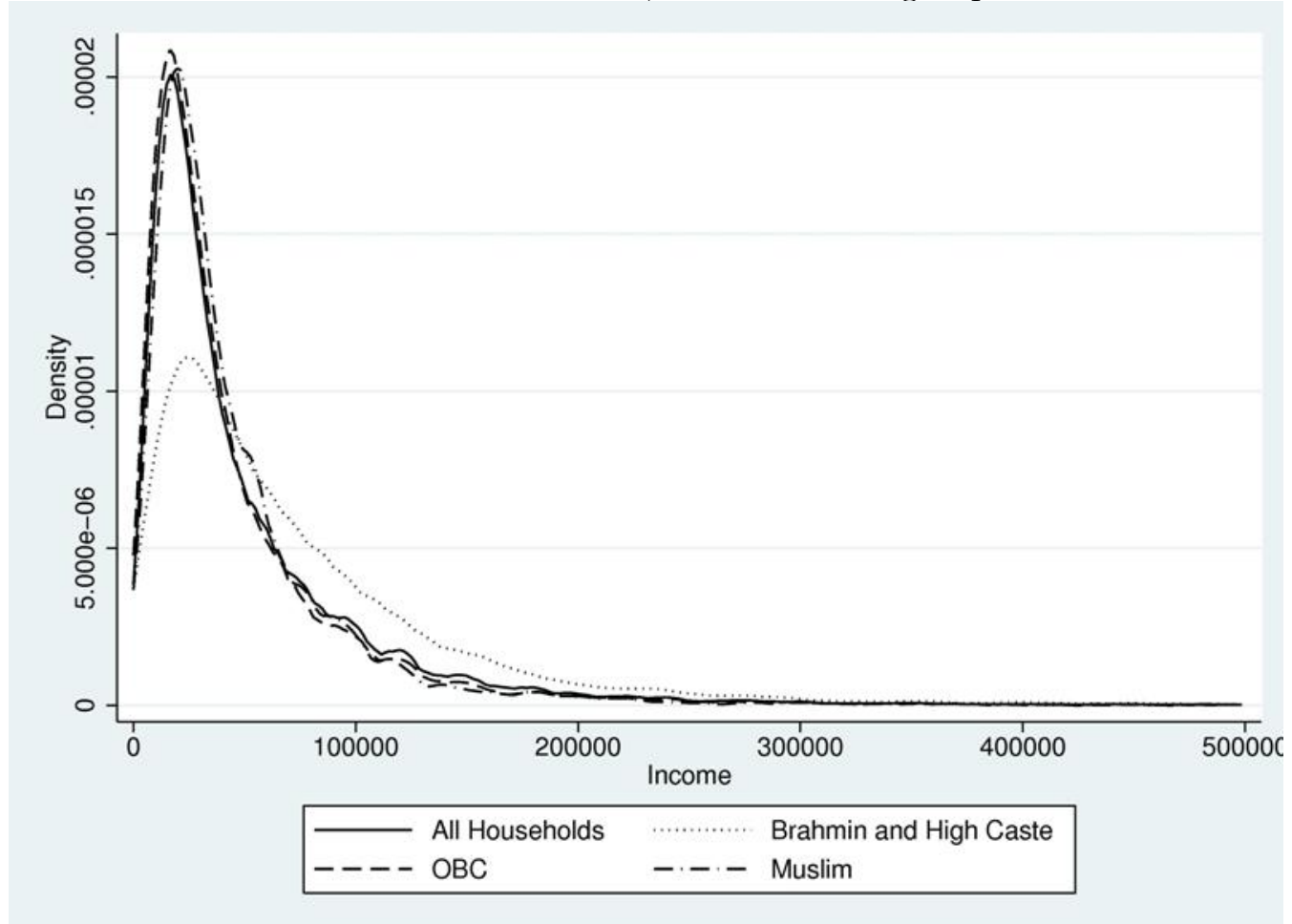

${ }^{1}$ Source: Authors' calculations based on the India Human Development Survey 2004-05, estimation sample as described in the paper.

${ }^{2}$ Distribution estimated by using Epanechnikov Kernel. 


\section{Figure 2}

Distribution of Total Expenditures, selected social groups

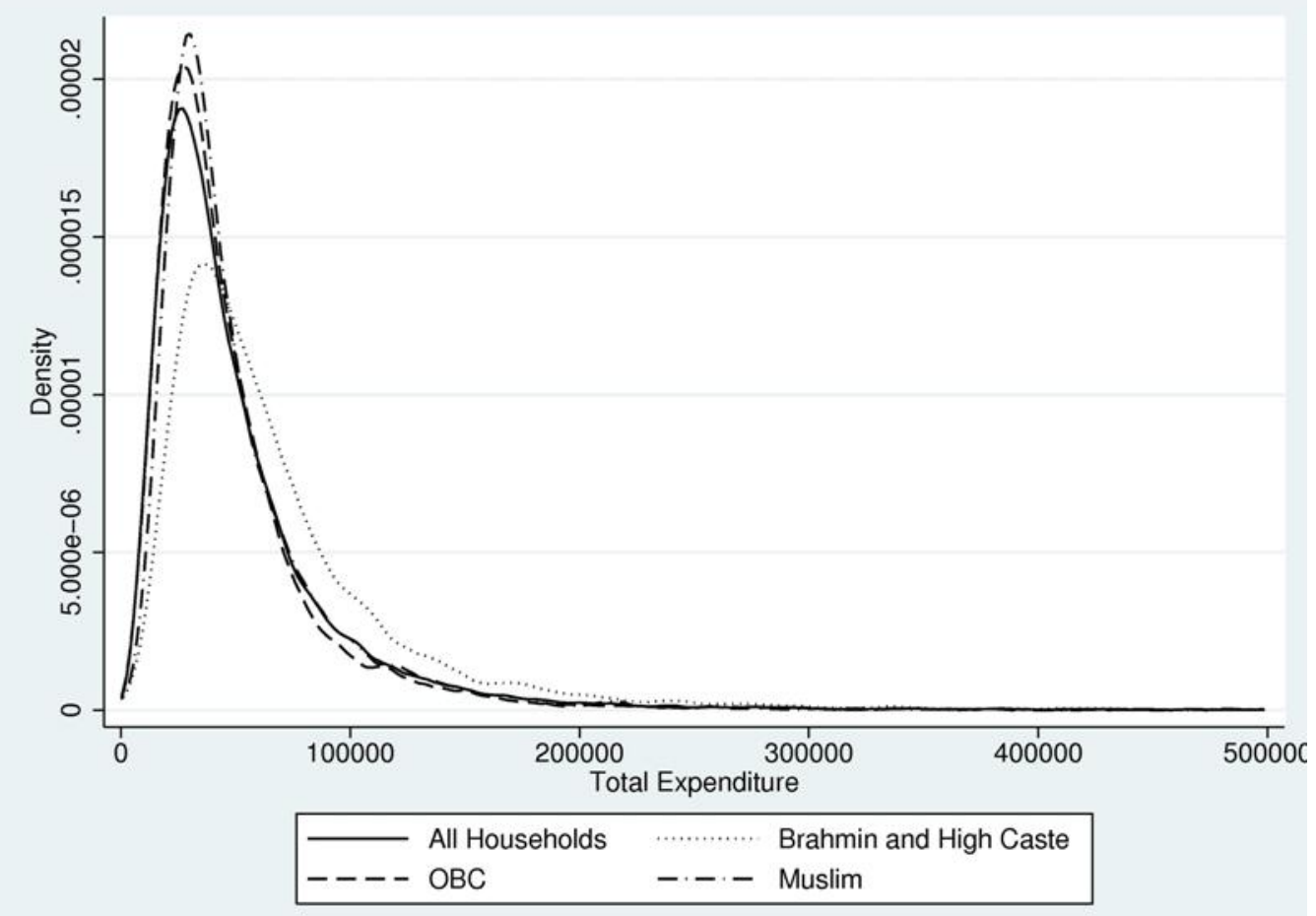

${ }^{1}$ Source: Authors' calculations based on the India Human Development Survey 2004-05, estimation sample as described in the paper.

${ }^{2}$ Distribution estimated by using Epanechnikov Kernel. 
Figure 3

Distribution of Expenditures on Visible items, selected social groups

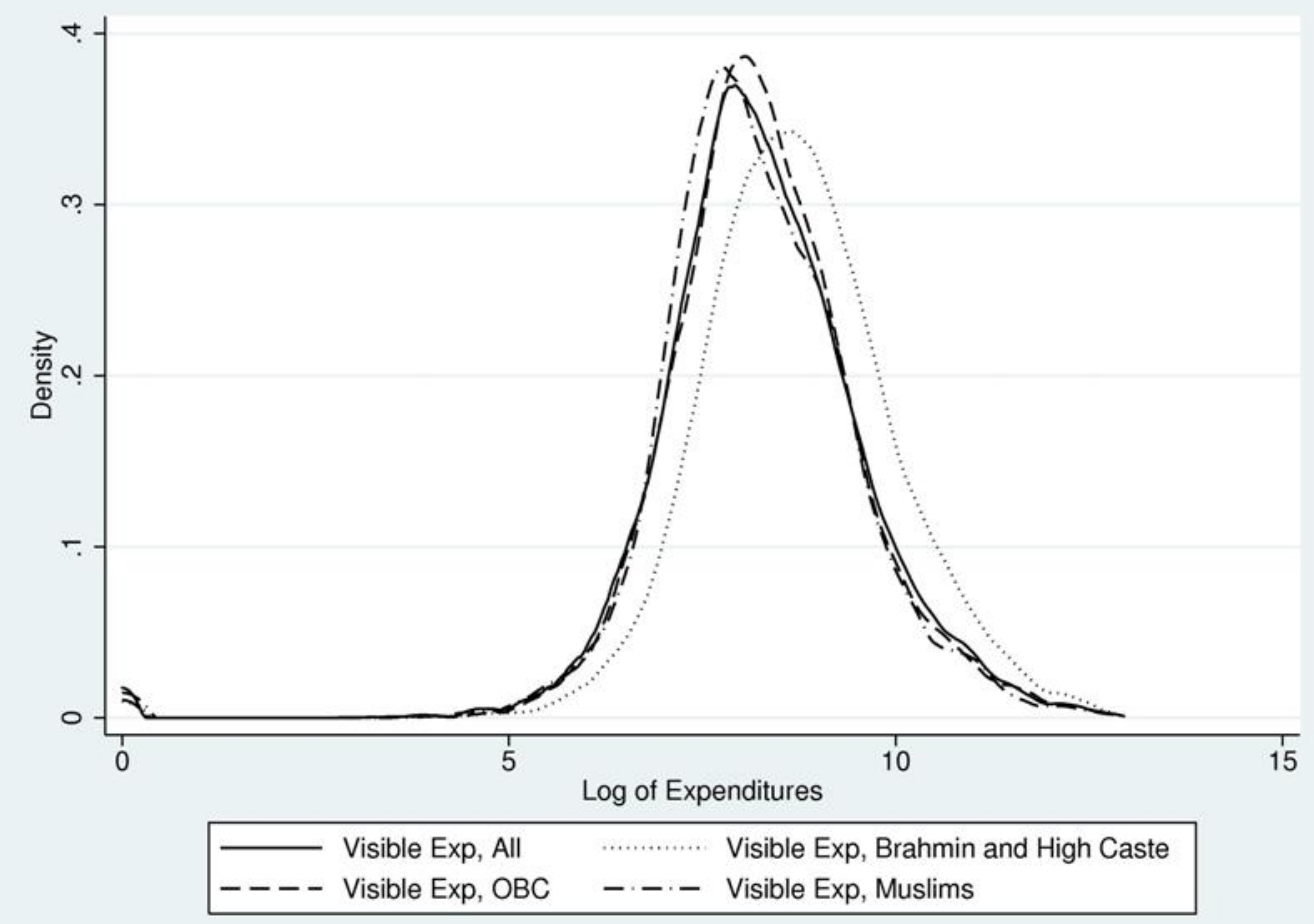

${ }^{1}$ Source: Authors' calculations based on the India Human Development Survey 2004-05, estimation sample as described in the paper.

${ }^{2}$ Distribution estimated by using Epanechnikov Kernel. 


\section{Figure 4}

Visible Spending Engel Curves, selected social groups

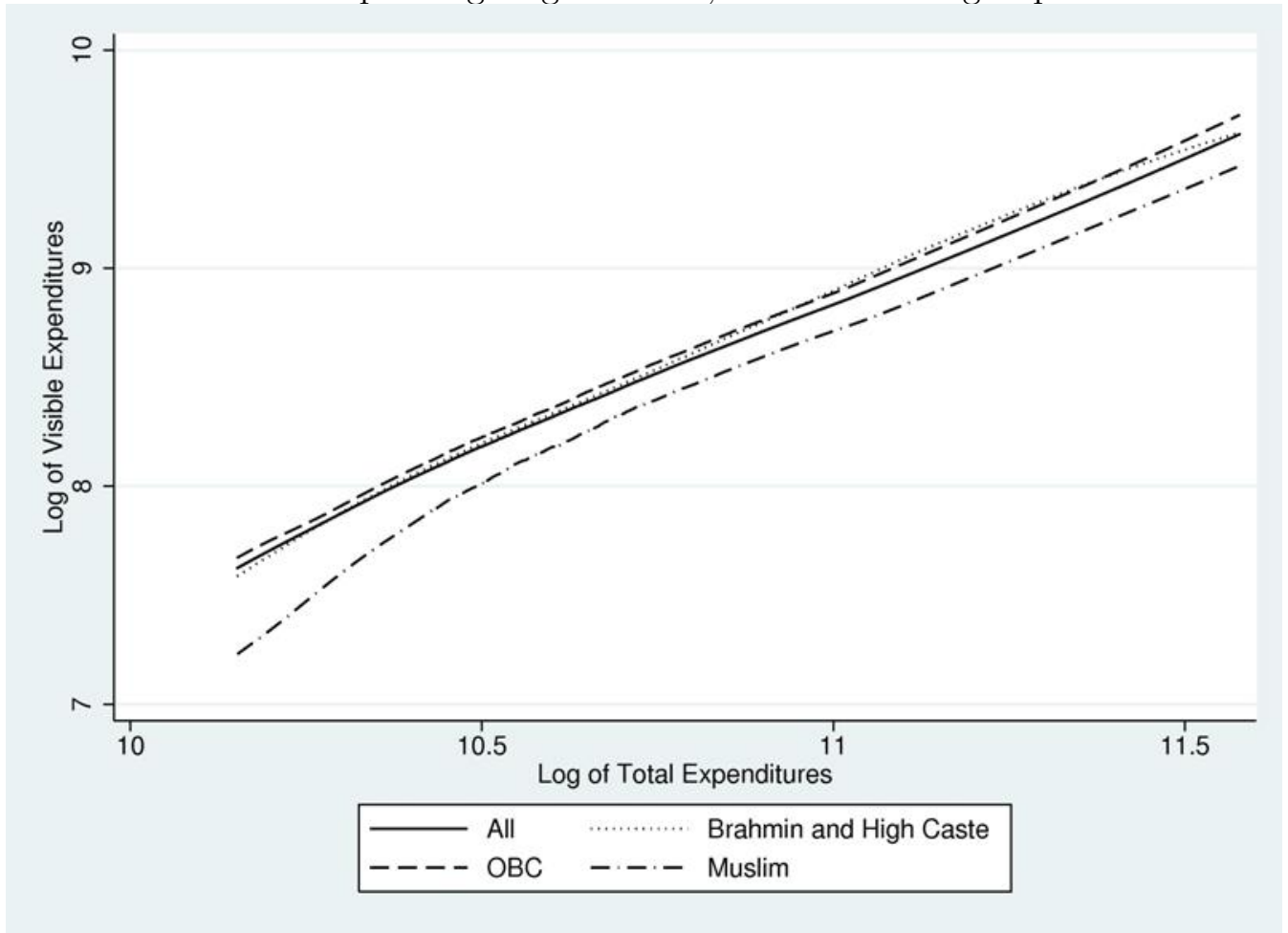

${ }^{1}$ Source: Authors' calculations based on the India Human Development Survey 2004-05.

${ }^{2}$ Expenditures on visible spending are the sum of (annualized) non-zero household expenditures on personal transport equipment, footwear, vacations, furniture and fixtures, social functions, repair and maintenance, house rent and rent, entertainment, clothing and bedding, jewelry and ornaments, recreation goods and personal goods.

${ }^{3}$ Engel curves are estimated for each social group by estimating locally weighted regression of non-zero $\ln$ (Visible Spending) on $\ln$ (Total Expenditure). $\ln$ (Total Expenditure) is instrumented using the vector $I$ (Current Income, $\ln ($ Current Income), the square of current income, the cube of current income, a dummy variable which takes the value one when Current Income is equal to zero and years of education). The regressions are estimated over a range populated by all social groups. These are households with $\ln$ (Total Expenditures) greater than 10.15 and less than 11.58. These values of $\ln$ (Total Expenditures) are approximately the first percentile of $\ln$ (Total Expenditures) for Muslim households and the ninety-ninth percentile of $\ln$ (Total Expenditures) for OBC households. 


\section{Figure 5}

\section{Education Spending Engel Curves, selected social groups}

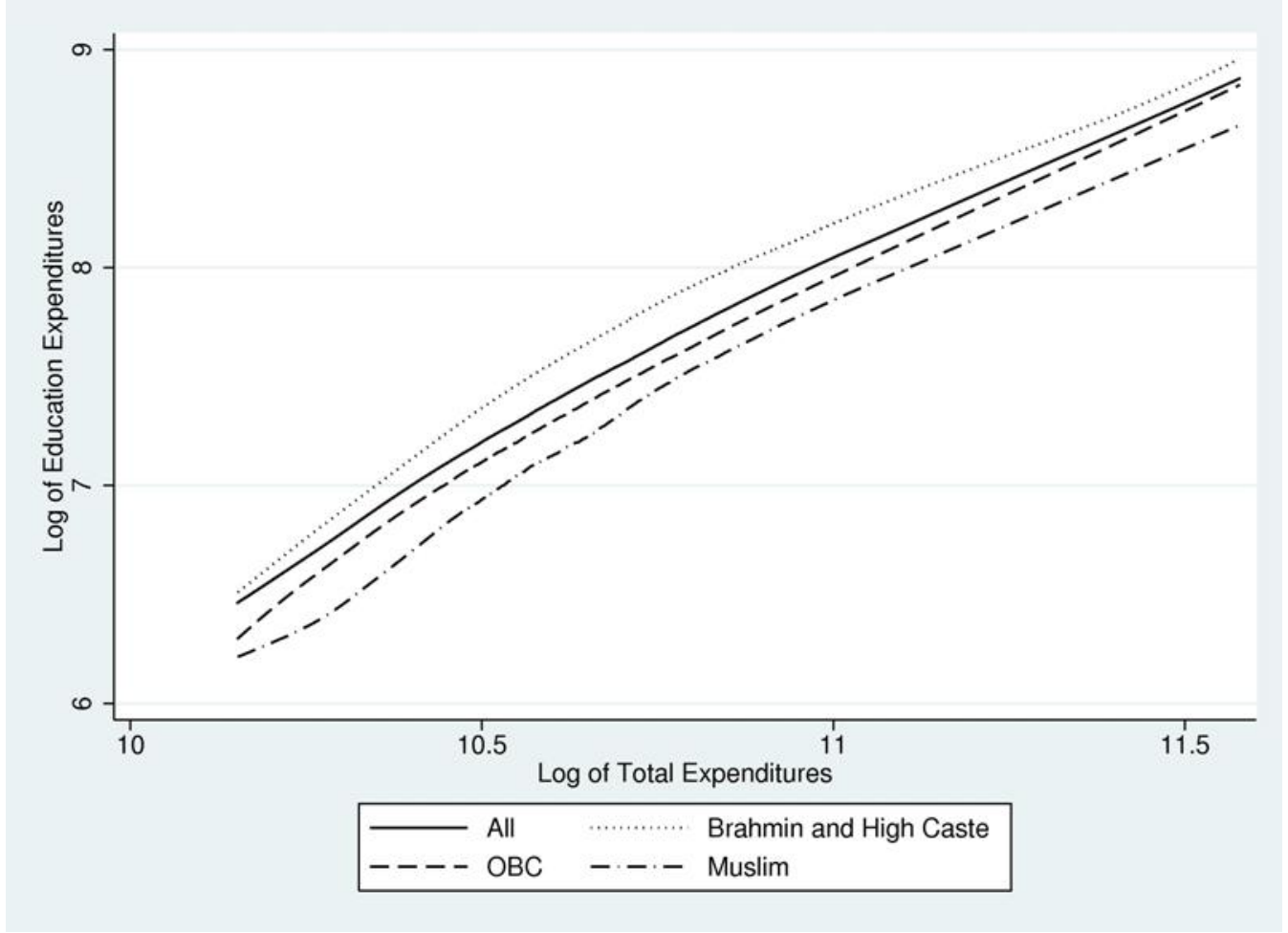

${ }^{1}$ Source: Authors' calculations based on the India Human Development Survey 2004-05.

2 Expenditures on education are the sum of (annualized) non-zero household expenditures on school/private tuition fees (including private tutor, school/college tuition fees) and on school books and other educational articles (including newspaper, library charges, stationary and internet charges).

3 Engel curves are estimated for each social group by estimating locally weighted regression of non-zero $\ln$ (Education Spending) on $\ln$ (Total Expenditure). $\ln$ (Total Expenditure) is instrumented using the vector $I$ (Current Income, $\ln ($ Current Income), the square of current income, the cube of current income, a dummy variable which takes the value one when Current Income is equal to zero and years of education). The regressions are estimated over a range populated by all social groups. These are households with $\ln$ (Total Expenditures) greater than 10.15 and less than 11.58. These values of $\ln$ (Total Expenditures) are approximately the first percentile of $\ln$ (Total Expenditures) for Muslim households and the ninety-ninth percentile of $\ln$ (Total Expenditures) for OBC households. 


\section{Figure 6}

Health Spending Engel Curves, selected social groups

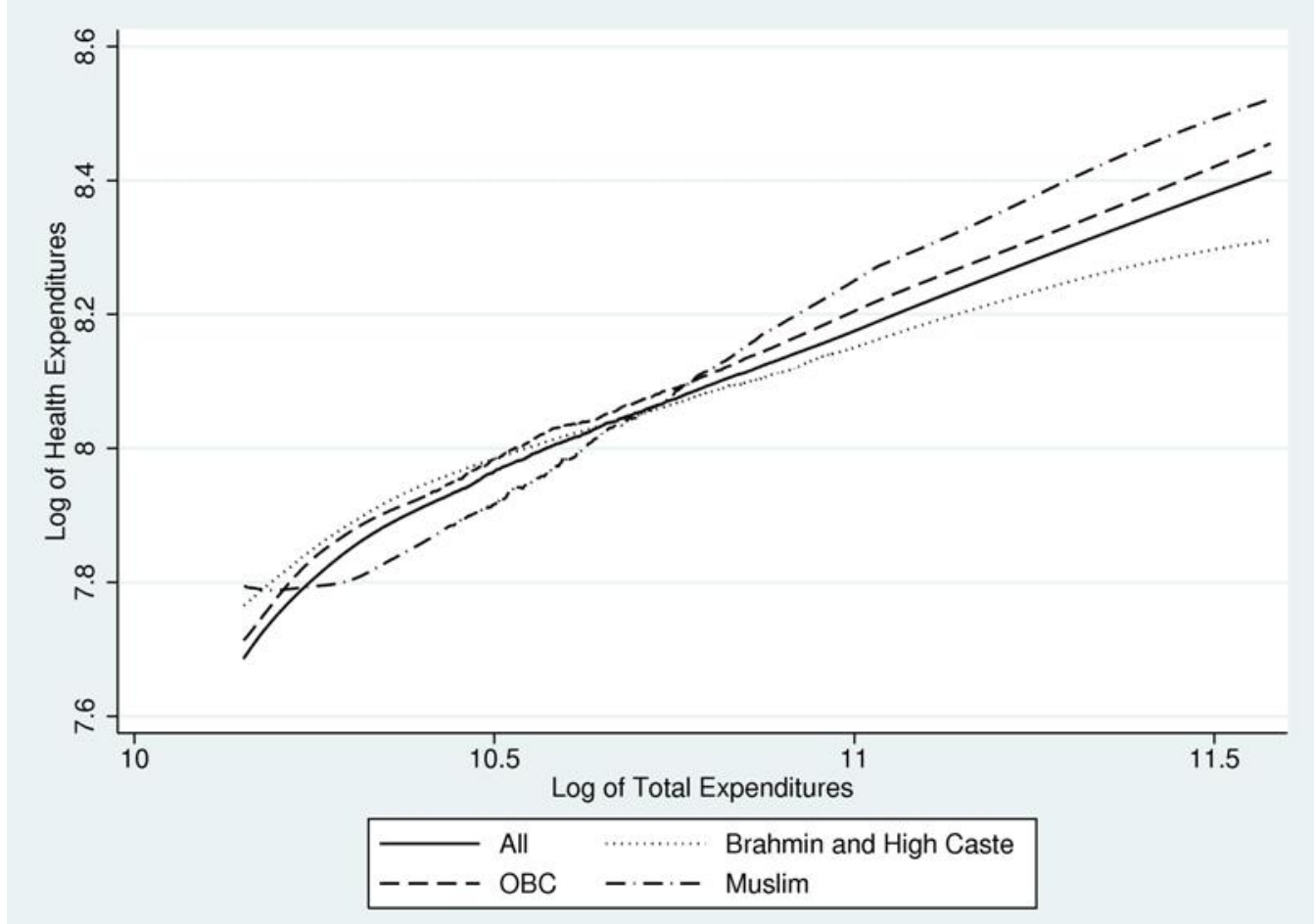

${ }^{1}$ Source: Authors' calculations based on the India Human Development Survey 2004-05.

${ }^{2}$ Expenditures on health are the sum of (annualized) non-zero household expenditures on medical expenses (out patient services) and medical in-patient services.

${ }^{3}$ Engel curves are estimated for each social group by estimating locally weighted regression of non-zero $\ln ($ Health Spending) on $\ln$ (Total Expenditure). $\ln$ (Total Expenditure) is instrumented using the vector $I$ (Current Income, $\ln ($ Current Income), the square of current income, the cube of current income, a dummy variable which takes the value one when Current Income is equal to zero and years of education). The regressions are estimated over a range populated by all social groups. These are households with $\ln$ (Total Expenditures) greater than 10.15 and less than 11.58. These values of $\ln$ (Total Expenditures) are approximately the first percentile of $\ln$ (Total Expenditures) for Muslim households and the ninety-ninth percentile of $\ln$ (Total Expenditures) for OBC households. 
Figure 7

Food Spending Engel Curves, selected social groups

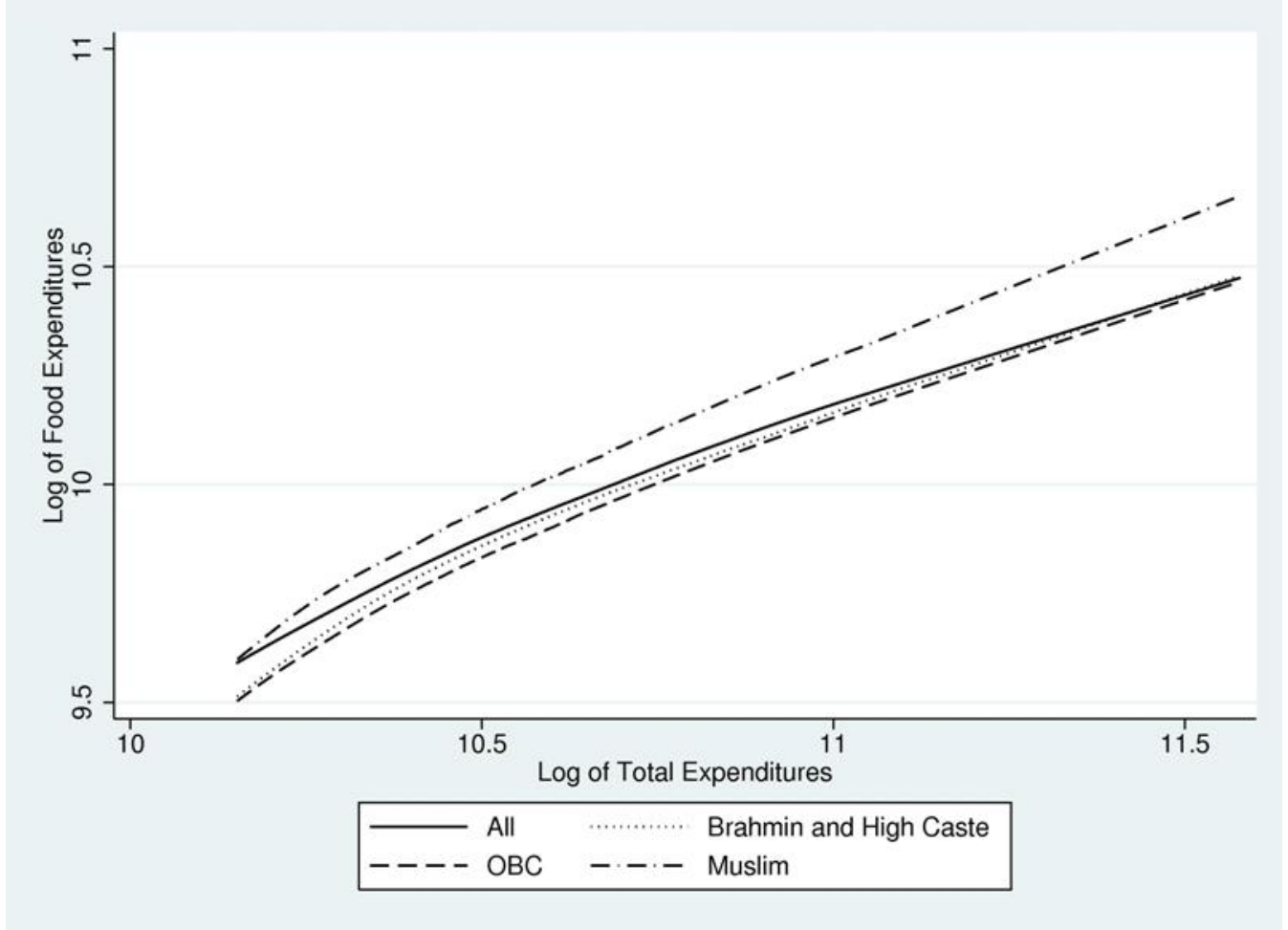

${ }^{1}$ Source: Authors' calculations based on the India Human Development Survey 2004-05.

${ }^{2}$ Expenditures on food are the sum of (annualized) non-zero household expenditures on rice, wheat, kerosene, other cereals, cereal products, pulse and pulse products, meat chicken and fish, gur and other sweeteners, edible oil and vanaspiti, eggs, milk, milk products, salt and spices, processed foods and fruits and nuts.

${ }^{3}$ Engel curves are estimated for each social group by estimating locally weighted regression of non-zero $\ln$ (Food Spending) on $\ln$ (Total Expenditure). $\ln$ (Total Expenditure) is instrumented using the vector $I$ (Current Income, $\ln$ (Current Income), the square of current income, the cube of current income, a dummy variable which takes the value one when Current Income is equal to zero and years of education). The regressions are estimated over a range populated by all social groups. These are households with $\ln$ (Total Expenditures) greater than 10.15 and less than 11.58. These values of $\ln$ (Total Expenditures) are approximately the first percentile of $\ln$ (Total Expenditures) for Muslim households and the ninety-ninth percentile of $\ln$ (Total Expenditures) for OBC households. 


\section{A Categorizing Consumption}

\section{TABLE A.1}

Descriptive Statistics, Delhi School of Economics Survey $(N=163)$

\begin{tabular}{llc}
\hline $\begin{array}{l}\text { Female } \\
\text { Married } \\
\text { Religion }\end{array}$ & & 57.41 \\
& & 2.6 \\
& Christian & 1.26 \\
& Hindu & 93.08 \\
& Jain & 1.89 \\
& Muslim & 0.63 \\
& Sikh & 3.14 \\
& Other & 1.26 \\
Social Group & & \\
& Scheduled Caste & 3.82 \\
& Scheduled Tribe & 2.55 \\
& Other Backward Caste & 5.73 \\
& Brahmin & 27.66 \\
& High Caste (other than Brahmin) & 45.86 \\
& Other & 20.38 \\
\hline
\end{tabular}

\footnotetext{
1 All items in percentages.
} 


\section{TABLE A.2}

Item Visibility and association with Income for selected items, Delhi School of Economics Survey $(N=163)$

\begin{tabular}{|c|c|c|}
\hline $\begin{array}{l}\text { (I) } \\
\text { Item }\end{array}$ & $\begin{array}{c}(\mathrm{II}) \\
\% \text { reporting }(\mathrm{I}) \\
\text { is easily observable }\end{array}$ & $\begin{array}{c}(\mathrm{III}) \\
\% \text { reporting }(\mathrm{I}) \\
\text { has income elasticity } \\
\geq 1\end{array}$ \\
\hline Personal transport equipment & 52.83 & 31.37 \\
\hline Footwear & 39.42 & 23.30 \\
\hline Vacations & 33.02 & 48.08 \\
\hline Furniture and fixtures & 32.08 & 25.24 \\
\hline Social Functions & 28.85 & 35.92 \\
\hline Repair and maintenance & 27.36 & 22.12 \\
\hline House rent, rent & 25.71 & 25.96 \\
\hline Entertainment & 23.81 & 50.49 \\
\hline Clothing and bedding & 23.81 & 27.18 \\
\hline Jewelry and ornaments & 22.86 & 53.40 \\
\hline Recreation goods & 20.95 & 45.63 \\
\hline Personal goods & 20.95 & 44.12 \\
\hline Paan, tobacco, intoxicants & 35.85 & 19.23 \\
\hline Services & 33.96 & 18.27 \\
\hline Food at restaurants & 19.23 & 44.23 \\
\hline Salt and Spices & 22.64 & 3.88 \\
\hline Fuel and light & 20.75 & 16.35 \\
\hline Telephone, cable, internet & 18.87 & 27.45 \\
\hline Personal care & 16.19 & 11.54 \\
\hline Insurance premiums & 2.91 & 31.07 \\
\hline
\end{tabular}

${ }^{1}$ (II) $\%$ of respondents who answered 1 or 2 to question on whether they can observe spending on specific item.

2 (III) \% of respondents answered 4 or 5 to question on how spending changes when income changes on specific item. 


\section{Details of the Visible Consumption Items:}

Personal Transport Equipment- includes bicycle, scooter, car, tyres, etc.

Footwear

Vacations

Furniture and Fixtures- includes bedstead, almirah, suitcase, carpet, paintings, etc.

Social Functions- marriage, funerals, gifts, etc.

Repair and maintenance- of residential buildings, bathroom equipment, etc.

House rent, rent- also for rented household appliances, furniture, etc.

Entertainment- includes cinema, picnic, sports, club fees, video cassettes.

Clothing and bedding

Jewelry and ornaments

Recreation goods- includes TV, radio, Tape recorder, musical instruments

Personal goods- includes clock, watch, PC, telephone, mobile, etc. 


\section{B Robustness Appendix}

TABLE B.1

Estimated Other Social Group-Brahmin/High Caste Gap in Log Visible Expenditure (excluding furniture and repairs)

\begin{tabular}{lcccccc}
\hline Regression Controls Included & OBC & Dalit & Adivasi & Muslim & Sikh/Jain & Christian \\
\hline (1) No additional controls & $-0.43^{* * *}$ & $-0.73^{* * *}$ & $-1.23^{* * *}$ & $-0.55^{* * *}$ & $0.35^{* * *}$ & $-0.16^{* *}$ \\
& $(0.02)$ & $(0.02)$ & $(0.04)$ & $(0.03)$ & $(0.06)$ & $(0.07)$ \\
& $-0.07^{* * *}$ & $-0.24^{* * *}$ & $-0.66^{* * *}$ & $-0.17^{* * *}$ & 0.10 & $-0.12^{*}$ \\
(2) Controls for Income & $(0.02)$ & $(0.02)$ & $(0.04)$ & $(0.03)$ & $(0.06)$ & $(0.05)$ \\
& -0.01 & $-0.11^{* * *}$ & $-0.19^{* * *}$ & $-0.23^{* * *}$ & -0.09 & $-0.10^{* *}$ \\
(3) Controls for Total Expenditure & $(0.02)$ & $(0.02)$ & $(0.03)$ & $(0.02)$ & $(0.05)$ & $(0.05)$ \\
& 0.03 & $-0.05^{* *}$ & $-0.08^{* *}$ & $-0.19^{* * *}$ & $-0.13^{* * *}$ & $-0.10^{*}$ \\
(4) Instrumenting for Total & $(0.02)$ & $(0.02)$ & $(0.03)$ & $(0.02)$ & $(0.05)$ & $(0.05)$ \\
Expenditure using Income & $0.05^{* * *}$ & -0.03 & $-0.07^{*}$ & $-0.16^{* * *}$ & $-0.14^{* * *}$ & $-0.12^{* * *}$ \\
(5) Specification (4) plus & $(0.02)$ & $(0.02)$ & $(0.03)$ & $(0.02)$ & $(0.05)$ & $(0.05)$ \\
demographic and other controls & & & & & &
\end{tabular}

${ }^{1}$ Source: Authors' calculations based on the India Human Development Survey 2004-05, estimation sample as described in the paper.

${ }^{2}$ Heteroscedasticity corrected robust standard errors reported in brackets.

$3 *$ significant at $5 \%, * *$ significant at $2.5 \%, * * *$ significant at $1 \%$

${ }^{4}$ Base Group: Brahmin and Other High Caste combined.

${ }^{5}$ Specification (1) includes only social group dummies in a regression on $\ln$ (Visible Spending, excluding furniture and repairs). Specification (2) estimates (1) with the addition of controls for Current Income, $\ln$ (Current Income), the square of current income, the cube of current income, a dummy variable which takes the value one when Current Income is equal to zero and years of education. Specification (3) estimates (1) with the addition of controls for $\ln$ (Total Expenditure). Specification (4) estimates (1) with the addition of instruments for $\ln ($ Total Expenditure); instruments include Current Income, $\ln ($ Current Income), the square of current income, the cube of current income, a dummy variable which takes the value one when Current Income is equal to zero and years of education. Specification (5) estimates (4) with the addition of controls for household assets, gender and age of household head, household size and a dummy variable for whether the household is located in an urban area. 


\section{TABLE B.2}

Estimated Other Social Group-High Caste Gap in Log of weighted Visible Expenditure

\begin{tabular}{lcccccc}
\hline Regression Controls Included & OBC & Dalit & Adivasi & Muslim & Sikh/Jain & Christian \\
\hline (1) No additional controls & $-0.40^{* * *}$ & $-0.63^{* * *}$ & $-1.05^{* * *}$ & $-0.42^{* * *}$ & $0.38^{* * *}$ & 0.03 \\
& $(0.02)$ & $(0.02)$ & $(0.02)$ & $(0.02)$ & $(0.04)$ & $(0.05)$ \\
& $-0.08^{* * *}$ & $-0.18^{* * *}$ & $-0.54^{* * *}$ & $-0.07^{* * *}$ & $0.15^{* * *}$ & 0.07 \\
(2) Controls for Income & $(0.01)$ & $(0.02)$ & $(0.02)$ & $(0.02)$ & $(0.03)$ & $(0.04)$ \\
& 0.00 & $-0.03^{* * *}$ & $-0.04^{* * *}$ & $-0.10^{* * *}$ & $-0.04^{* * *}$ & $0.08^{* * *}$ \\
(3) Controls for Total Expenditure & $(0.00)$ & $(0.00)$ & $(0.01)$ & $(0.01)$ & $(0.01)$ & $(0.01)$ \\
& 0.01 & $-0.02^{* * *}$ & $-0.02^{* * *}$ & $-0.10^{* * *}$ & $-0.05^{* * *}$ & $0.09^{* * *}$ \\
(4) Instrumenting for Total & $(0.00)$ & $(0.00)$ & $(0.01)$ & $(0.01)$ & $(0.01)$ & $(0.01)$ \\
Expenditure using Income & $0.03^{* * *}$ & $0.01^{*}$ & 0.00 & $-0.05^{* * *}$ & $-0.07^{* * *}$ & $0.05^{* * *}$ \\
(5) Specification (4) plus & $(0.00)$ & $(0.00)$ & $(0.01)$ & $(0.01)$ & $(0.01)$ & $(0.01)$ \\
demographic and other controls & & & & & &
\end{tabular}

${ }^{1}$ Source: Authors' calculations based on the India Human Development Survey 2004-05, estimation sample as described in the paper.

${ }^{2}$ Heteroscedasticity corrected robust standard errors reported in brackets.

$3 *$ significant at $5 \%, * *$ significant at $2.5 \%, * * *$ significant at $1 \%$

${ }^{4}$ Base Group: Brahmin and Other High Caste combined.

${ }^{5}$ Specification (1) includes only social group dummies in a regression on $\ln$ (weighted Visible Spending). Specification (2) estimates (1) with the addition of controls for Current Income, $\ln$ (Current Income), the square of current income, the cube of current income, a dummy variable which takes the value one when Current Income is equal to zero and years of education. Specification (3) estimates (1) with the addition of controls for $\ln$ (Total Expenditure). Specification (4) estimates (1) with the addition of instruments for $\ln$ (Total Expenditure); instruments include Current Income, $\ln$ (Current Income), the square of current income, the cube of current income, a dummy variable which takes the value one when Current Income is equal to zero and years of education. Specification (5) estimates (4) with the addition of controls for household assets, gender and age of household head, household size and a dummy variable for whether the household is located in an urban area. 